\title{
Historical black carbon deposition in the Canadian High Arctic: a > 250-year long ice-core record from Devon Island
}

\author{
Christian M. Zdanowicz ${ }^{1}$, Bernadette C. Proemse ${ }^{2}$, Ross Edwards ${ }^{3,4}$, Wang Feiteng ${ }^{5}$, Chad M. Hogan ${ }^{2}$, \\ Christophe Kinnard ${ }^{6}$, and David Fisher ${ }^{7}$ \\ ${ }^{1}$ Department of Earth Sciences, Uppsala University, Uppsala, 752 36, Sweden \\ ${ }^{2}$ School of Biological Sciences, University of Tasmania, Hobart, TAS 7001, Australia \\ ${ }^{3}$ Physics and Astronomy, Curtin University, Perth, WA 6102, Australia \\ ${ }^{4}$ Depart of Civil and Environmental Engineering, University of Wisconsin, Madison, WI 53706, USA \\ ${ }^{5}$ Cold and Arid Regions Environment and Engineering Research Institute, Chinese Academy of Sciences, Lanzhou, China \\ ${ }^{6}$ Département des Sciences de l'Environnement, Université du Québec à Trois-Rivières, \\ Trois-Rivières, G9A 5H7, QC, Canada \\ ${ }^{7}$ Department of Earth Sciences, University of Ottawa, 120 University, Ottawa, K1N 6N5, ON, Canada
}

Correspondence: Christian M. Zdanowicz (christian.zdanowicz@geo.uu.se)

Received: 27 September 2017 - Discussion started: 4 October 2017

Revised: 26 July 2018 - Accepted: 9 August 2018 - Published: 27 August 2018

\begin{abstract}
Black carbon aerosol (BC), which is emitted from natural and anthropogenic sources (e.g., wildfires, coal burning), can contribute to magnify climate warming at high latitudes by darkening snow- and ice-covered surfaces, and subsequently lowering their albedo. Therefore, modeling the atmospheric transport and deposition of $\mathrm{BC}$ to the Arctic is important, and historical archives of $\mathrm{BC}$ accumulation in polar ice can help to validate such modeling efforts. Here we present a $>250$-year ice-core record of refractory $\mathrm{BC}$ (rBC) deposition on Devon ice cap, Canada, spanning the years from 1735 to 1992 . This is the first such record ever developed from the Canadian Arctic. The estimated mean deposition flux of rBC on Devon ice cap for 1963-1990 is $0.2 \mathrm{mg} \mathrm{m}^{-2} \mathrm{a}^{-1}$, which is at the low end of estimates from Greenland ice cores obtained using the same analytical method ( $\left.\sim 0.1-4 \mathrm{mg} \mathrm{m}^{-2} \mathrm{a}^{-1}\right)$. The Devon ice cap rBC record also differs from the Greenland records in that it shows only a modest increase in $\mathrm{rBC}$ deposition during the 20th century. In the Greenland records a pronounced rise in $\mathrm{rBC}$ is observed from the 1880 s to the $1910 \mathrm{~s}$, which is largely attributed to midlatitude coal burning emissions. The deposition of contaminants such as sulfate and lead increased on Devon ice cap in the 20th century but no concomitant rise in $\mathrm{rBC}$ is recorded in the ice. Part of the difference with Greenland could be due to local factors such as melt-
\end{abstract}

freeze cycles on Devon ice cap that may limit the detection sensitivity of rBC analyses in melt-impacted core samples, and wind scouring of winter snow at the coring site. Air back-trajectory analyses also suggest that Devon ice cap receives BC from more distant North American and Eurasian sources than Greenland, and aerosol mixing and removal during long-range transport over the Arctic Ocean likely masks some of the specific BC source-receptor relationships. Findings from this study suggest that there could be a large variability in $\mathrm{BC}$ aerosol deposition across the Arctic region arising from different transport patterns. This variability needs to be accounted for when estimating the large-scale albedo lowering effect of BC deposition on Arctic snow/ice.

\section{Introduction}

The deposition of light-absorbing carbonaceous particles emitted by the incomplete combustion of biomass and fossil fuel can decrease the albedo of Arctic snow- and icecovered surfaces, thereby amplifying high-latitude warming driven by the buildup of greenhouse gas emissions (AMAP, 2011; Bond et al., 2013). The widely used expression "black carbon" (BC) designates the insoluble, refractory fraction of these aerosols that is largely made of graphitic elemen- 
tal carbon and strongly absorbs light at visible to nearinfrared wavelengths (Petzold et al., 2013). Along with sulfate $\left(\mathrm{SO}_{4}^{2-}\right), \mathrm{BC}$ is one of the main short-lived climate pollutants being targeted for mitigation and control under multinational legal agreements (Quinn et al., 2008; AMAP, 2015).

In order to evaluate how past and future BC emissions have affected, and will affect, climate forcing in the Arctic, global atmospheric climate models can be used to simulate the transport and deposition of $\mathrm{BC}$ aerosols in this region (Koch et al., 2011; Skeie et al., 2011; Lee et al., 2013; Jiao and Flanner, 2016). At present, simulated BC dispersion suffers from large biases, either positive or negative, compared with observational data on BC in Arctic air and snow (Jiao et al., 2014). Validating model simulations is difficult because of the scarcity of such observations across the Arctic. Direct monitoring of atmospheric BC is currently limited to a few decades and has only been carried out at a few stations (Hirdman et al., 2010; Gong et al., 2010), and geographic surveys of $\mathrm{BC}$ in snow and ice are rare and difficult to conduct over the vast Arctic region (e.g., Doherty et al., 2010).

Ice cores drilled from the accumulation area of glaciers and ice caps can be used as surrogates for direct atmospheric observations, as they contain archives of BC and other aerosol species deposited in snow over many centuries (McConnell, 2010). At present, ice-core records of BC deposition in the Arctic region are only available from Greenland (McConnell et al., 2007; McConnell and Edwards, 2008; Zennaro et al., 2014; Sigl et al., 2015) and from Svalbard, Norway (Ruppel et al., 2014). Here, for the first time, we present a historical record of $\mathrm{BC}$ deposition in the Canadian Arctic, developed from a core drilled on Devon Island ice cap, and roughly spanning the years from 1735 to 1992 . The Devon ice cap BC record presents some striking differences from Greenland ice-core records of $\mathrm{rBC}$ concentrations developed using the same methods. We discuss the possible reasons for these differences, and consider the implications with respect to regional $\mathrm{BC}$ transport and deposition patterns in the Arctic region.

\section{Study site}

At latitude $75^{\circ} \mathrm{N}$, Devon ice cap $\left(14400 \mathrm{~km}^{2}\right)$ occupies a central position in the eastern Canadian Arctic Archipelago and lies $275 \mathrm{~km}$ from the Greenland coast across northern Baffin Bay. The ice cap has been studied for half a century (Boon et al., 2010) and was previously drilled to obtain records of climate and atmospheric contaminants (e.g., GotoAzuma and Koerner, 2001; Shotyk et al., 2005; Kinnard et al., 2006). However, no record of BC deposition was ever developed from this or any other site in the Canadian Arctic. The core used in the present study (DV99.1) was obtained in April 1999 by the Geological Survey of Canada (GSC) at the top of a dome $\left(75.32^{\circ} \mathrm{N}, 81.64^{\circ} \mathrm{W}, 1903 \mathrm{~m}\right.$ a.s.l.) located $25 \mathrm{~km}$ east of the ice cap's main dome and true sum- mit ( 1930 m.a.s.l.) (Fig. 1). The coring site lies above the present-day equilibrium line which, based on long-term mass balance observations, has a mean altitude of $1150 \mathrm{~m}$ a.s.l. The mean annual air temperature at the summit of Devon ice cap is $-22^{\circ} \mathrm{C}$ (Bezeau et al., 2013), and the estimated mean accumulation rate $(\dot{A})$ at the DV99.1 coring site is $0.14 \mathrm{~m}$ ice $\mathrm{a}^{-1}$, or $0.16 \mathrm{~m} \mathrm{H}_{2} \mathrm{O} \mathrm{a}^{-1}$ (see below).

\section{Materials and methods}

\subsection{Core sampling and analyses}

The DV99.1 core was recovered in $0.4-1.1 \mathrm{~m}$ long increments (average $0.9 \mathrm{~m}$ ), with a diameter of $9.8 \mathrm{~cm}$. The uppermost $2.8 \mathrm{~m}$ of the core was made of crumbly firn, and was not preserved at the time of drilling. The solid-state DC electrical conductivity (EC) of the core was measured continuously in the field using a hand-held system with parallel electrodes (Icefield Instruments Inc., Whitehorse, Canada), as described in Zheng et al. (1998). The EC profiling started at a depth of $12.38 \mathrm{~m}$, because sections of cores above this were of brittle firn that provided inadequate electrode contact for the handheld instrument. The core was shipped and stored in freezers at the GSC ice-core laboratory in Ottawa. There, it was sampled at $5-20 \mathrm{~cm}$ resolution for the subsequent determination of stable oxygen isotope ratios $\left(\delta^{18} \mathrm{O}\right)$ by mass spectrometry at the University of Copenhagen. Later, 57 discrete subsamples from depths below $29 \mathrm{~m}$ were analyzed for lead $(\mathrm{Pb})$ and other trace metals, as reported in Zheng et al. (2007). The remaining cores were stored frozen $\left(-20^{\circ} \mathrm{C}\right)$ inside sealed polyethylene bags, until archived core segments between 2.8 and $48 \mathrm{~m}$ depths were selected for this study and shipped, still frozen, to Curtin University in Australia for BC analyses. These combined core segments were estimated to span $>250$ years, as explained below.

Sample preparation and analysis was conducted between 6 and 11 December 2012 at the Trace Research Clean Environmental facility at Curtin University. The facility consists of a large class 100 space containing multiple class 10 laboratory modules including $\mathrm{a}-20^{\circ} \mathrm{C}$ walk-in freezer within a general lab space (also class 10 ). The space was specifically designed for trace metal and particle work on ice cores (e.g., BurnNunes et al., 2011, Ellis et al., 2015, 2016; Tuohy et al., 2015; Vallelonga et al., 2017). The DV99.1 core sections were cut into subsamples with a $\sim 2.5 \times 2.5 \mathrm{~cm}$ cross section, which were processed in an ice-core melter coupled to a continuous flow analysis (CFA) system (see Supplement, Fig. S1). Icecore preparation was carried out in the walk-in freezer, while processing in the CFA system was conducted in the general lab class 100 space. The CFA melter system was similar to that described by McConnell et al. (2002) with the exception that the ice-core melter head was made from aluminum. The method used to quantify BC in the ice core was the same as that used for the analysis of Greenland and Antarc- 


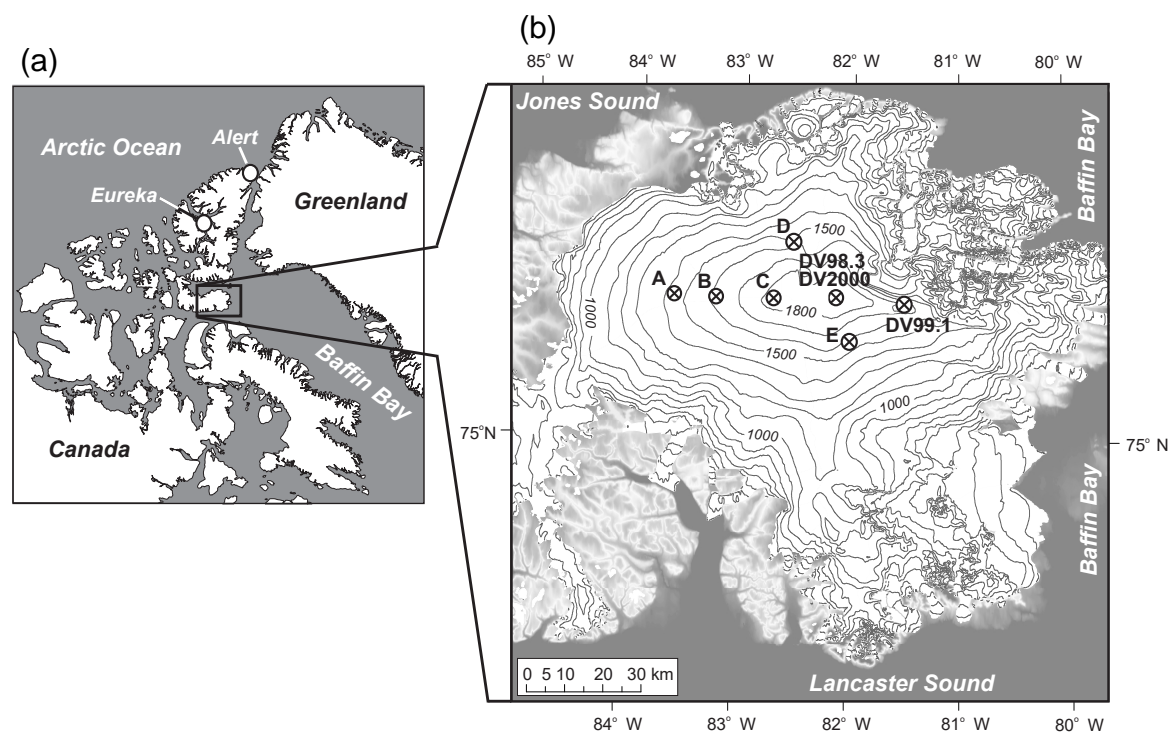

Figure 1. Location map of the Canadian Arctic Archipelago (a), with enlargement of Devon ice cap (b). The location of the various ice-core sites mentioned in the text are shown. Sites A to E refer to the shallow core array of Colgan and Sharp (2008). Elevation contours on Devon ice cap are spaced at $100 \mathrm{~m}$ above sea level.

tic cores (see Bisiaux et al., 2012; McConnell et al., 2007; McConnell and Edwards, 2008; Zennaro et al., 2014). Meltwater from the CFA system was aerosolized and desolvated with a U5000AT ultrasonic nebulizer (CETAC Technologies, Omaha, NE, USA) and injected into a single-particle intracavity laser-induced incandescence photometer (Schwarz et al., 2010; SP2, Droplet Measurement Technologies, Boulder, $\mathrm{CO}$ ), which measured the mass concentration of $\mathrm{BC}$ particles in the meltwater flow. Instrumental settings are given in the Supplement (Table S1). Following Petzold et al. (2013), we refer to the $\mathrm{BC}$ fraction measured by this method as "refractory $\mathrm{BC}$ " $(\mathrm{rBC})$, reported here in mass concentration units of $\operatorname{ng~g}^{-1}$.

On each day of the analysis, a log journal was created. The length of every piece of the DV99.1 core was carefully measured prior to analysis. During CFA, the time of each break between two ice-core pieces was recorded, making it possible to reconcile the $\mathrm{rBC}$ record of each piece based on the time-depth log. The flow rate of the CFA to the nebulizer was controlled by oversupplying a $<1 \mathrm{~mL}$ debubbling vessel with excess water, which allowed the instrument to maintain a very constant flow rate. External calibration of the SP2 nebulizer system was achieved using eight standards of $100 \%$ carbon black pigment (MIS Ink Supply, Eboni-6K; Fig. S2) spanning a concentration range of $0-20 \mathrm{ng} \mathrm{g}^{-1}$. The standards were analyzed each day before and after ice-core analysis and the results were compared to assess the stability, reproducibility, and measurement uncertainty of the SP2. Additional details and calibration curves (Figs. S3-S6) are provided in the Supplement, and potential sources of uncertainty in the results are discussed in Sect. 3.3.
To compare the DV99.1 record of $\mathrm{rBC}$ with that of other deposited aerosol species, we used glaciochemical data obtained from two other cores drilled from the summit area of Devon ice cap in 1998 (core DV98.3) and 2000 (core DV2000) (Fig. 1; Table 1). The DV98.3 core was sampled continuously and analyzed for eight major ionic species by ion chromatography, as described in Kinnard et al. (2006). In this study, we used $\mathrm{SO}_{4}^{2-}$, sodium $\left(\mathrm{Na}^{+}\right)$, calcium $\left(\mathrm{Ca}^{2+}\right)$, potassium $\left(\mathrm{K}^{+}\right)$, and ammonium $\left(\mathrm{NH}_{4}^{+}\right)$data obtained from the top $85 \mathrm{~m}$ of the core, which had been sampled at $3-12 \mathrm{~cm}$ resolution. The non-sea salt fraction of sulfur (nssS) was estimated from $\mathrm{Na}^{2+}$ using the mean surface seawater composition of Pilson (2012), whilst the biomass burning fraction (BB) of $\mathrm{K}^{+}$was estimated from $\mathrm{Na}^{2+}$ and $\mathrm{Ca}^{2+}$ as follows: $\left[\mathrm{K}^{+}\right]_{\mathrm{BB}}=\left[\mathrm{K}^{+}\right]-\left(0.038 \times\left[\mathrm{Na}^{+}\right]\right)-\left(0.04 \times\left[\mathrm{Ca}^{2+}\right]\right)$, following Legrand et al. (2016). The DV2000 core was drilled at the same site as the DV98.3 core, and was analyzed for $\mathrm{Pb}$ and other metals, as reported in Shotyk et al. (2005). However, the remaining archived volume from cores DV98.3 and DV2000 was insufficient to carry out rBC analyses, which is why core DV99.1 was used for this purpose.

\subsection{Age models}

Annual layers are not easily resolved in cores from Canadian Arctic ice caps, partly owing to relatively low $\dot{A}$, but also due to the effects of wind and/or summer surface melt. Therefore, age models developed for these cores are commonly based on a variety of alternative methods. For the DV98.3 and DV99.1 cores, an ice-flow model (Dansgaard and Johnsen, 1969) was used, constrained by the total ice thickness obtained from ice- 
Table 1. Details of the three Devon ice cap cores used in this study. MAAT refers to mean annual surface air temperature. See text for specific references to published data.

\begin{tabular}{lrrrrrrl}
\hline Core & $\begin{array}{r}\text { Lat. } \\
(\mathrm{N})\end{array}$ & $\begin{array}{r}\text { Lon. } \\
(\mathrm{W})\end{array}$ & $\begin{array}{r}\text { Max. depth } \\
(\mathrm{m})\end{array}$ & $\begin{array}{r}\text { Approx. elevation } \\
(\mathrm{m} \text { a.s.1.) }\end{array}$ & $\begin{array}{r}\text { MAAT } \\
\left({ }^{\circ} \mathrm{C}\right)\end{array}$ & $\begin{array}{r}\text { Annual accum. } \\
\left(\mathrm{m} \mathrm{H} \mathrm{H}_{2} \mathrm{O}\right)\end{array}$ & Parameters measured \\
\hline DV98.3 & $75.34^{\circ}$ & $82.14^{\circ}$ & 302 & 1930 & -12 & $0.25-0.28$ & $\begin{array}{l}\delta^{18} \mathrm{O} \text {, radioactivity, } \\
\text { major ions, and trace metals }\end{array}$ \\
& & & & & & & \\
DV99.1 & $75.32^{\circ}$ & $81.64^{\circ}$ & 169 & 1903 & no data & 0.16 & $\delta^{18} \mathrm{O}$, melt features, EC, and rBC \\
DV2000 & $75.34^{\circ}$ & $82.14^{\circ}$ & 64 & 1930 & -12 & $0.25-0.28$ & $\delta^{18} \mathrm{O}$, radioactivity, and trace metals \\
\hline
\end{tabular}

radar measurements or from borehole depths, and by the estimated $\dot{A}$ at each coring site. For the DV98.3 core, the age model was further constrained by approximate layer counting using $\delta^{18} \mathrm{O}$ and glaciochemical data at shallow depths. At greater depths, reference horizons from bomb radioactive fallout (1963; Pinglot et al., 2003) and historical volcanic eruptions were used, including the Laki volcanic eruption in Iceland, in 1783 (All given dates are C.E.), which is one of most recognizable historical volcanic signals recorded in EC and/or $\mathrm{SO}_{4}^{2-}$ records of other Canadian Arctic ice caps (e.g., Zheng et al., 1998; Goto-Azuma et al., 2002). The age model in the upper $48 \mathrm{~m}$ of the DV99.1 core was constrained using a reference horizon provided by a large EC (acidity) spike at a depth of $42.60 \mathrm{~m}$ (29.56 $\mathrm{m}$ ice equivalent), which was attributed to the 1783 Laki eruption (Fig. 2). This model gives an estimated maximum age of 1735 for the section of the DV99.1 core used in the present study, and the last year in the record is 1992. The age model also gave an acceptable agreement between profiles of various measured parameters in the DV98.3 and DV99.1 cores (Figs. S7-S8). The DV2000 core was drilled at the same site as the DV98.3 core and used the same age model. The two cores were correlated using measurements in the DV2000 that allowed for the identification of radioactive layers dated to 1958 (16.5 m depth) and 1963 (13.5 m depth) (Krachler et al., 2005). The DV2000 core was estimated to extend back to 1842 .

Using the Laki 1783 reference layer, the estimated $\dot{A}$ at the DV99.1 site is $0.14 \mathrm{mice}^{-1}\left(0.16 \mathrm{~m} \mathrm{H}_{2} \mathrm{O} \mathrm{a}^{-1}\right)$ which is lower than at the ice cap summit $\left(\sim 0.25-0.28 \mathrm{~m} \mathrm{H}_{2} \mathrm{O} \mathrm{a}^{-1}\right)$ or at sites elsewhere in the Devon ice cap accumulation zone (0.17-0.25 $\mathrm{m} \mathrm{H}_{2} \mathrm{O} \mathrm{a}^{-1}$; Colgan and Sharp, 2008). The most likely explanation for this is partial scouring of winter snow layers by downslope winds at the DV99.1 site, as also observed on parts of the Agassiz ice cap (Fisher et al., 1983). This is supported by a comparison of the $\delta^{18} \mathrm{O}$ measurements in the DV99.1 and DV98.3 cores, which shows that $\delta^{18} \mathrm{O}$ variations in the DV99.1 core are truncated of their most negative ("coldest") values relative to the DV98.3 core (Fig. S9). An estimate of the amount of snow lost by wind scouring at the DV99.1 site can be made from the difference in the amplitude of the $\delta^{18} \mathrm{O}$ data at the DV98.3 and DV99.1 sites, and from $\dot{A}$ at the DV98.3 site, following Fisher and Koerner (1988). The calculation suggests that $\sim 40 \%-45 \%$ of the annual snow accumulation is removed by wind at this site, compared to the summit of Devon ice cap.

\subsection{Quantifying uncertainties in the $\mathrm{rBC}$ record}

Analyses of rBC in the DV99.1 core were performed at high depth resolution, producing $\sim 55-80$ data points per meter over most of the core's length. The data were subsequently averaged over discrete depth increments equivalent to $\sim 1$-year and $\sim 10$-year intervals, respectively, based on the core's age model. In this paper, annually averaged figures are used for illustrative purposes only, as individual years can not be confidently resolved in the DV99.1 core. Down-core variations of $\mathrm{rBC}$ in the ice core are the result of a combination of processes, including temporal changes in atmospheric deposition rates (fluxes, abbreviated $F$ ), spatial variations of deposition of aerosols in snow, and post-depositional modifications (e.g., by wind scouring or summer surface melt). Additional uncertainties in the $\mathrm{rBC}$ data come from the age model of the ice core (Fig. 2) and from limitations of the analytical method.

The largest uncertainty with regards to the $\mathrm{rBC}$ analysis is due to the nebulization/desolvation step before the SP2 analysis. At the time of this study we had adopted nebulizer/desolvation systems used as a front end to inductively coupled plasma mass spectrometers (ICP-MS). These systems are designed to deliver appropriate aerosol size distributions for analysis in the ICP-MS. Schwarz et al. (2012) and Wendl et al. (2014) report rBC size-dependent losses during nebulization/desolvation for several types of nebulizer desolvation systems. The study found that the system used in this investigation had a poor transport efficiency for $\mathrm{rBC}$ particles with a volume equivalent diameter $>500 \mathrm{~nm}$. Hence, rBC data from the DV99.1 core should be considered with this limitation in mind (see Sect. 4.2 for a discussion). Other published ice-core data sets from Greenland (e.g., Mc Connell et al., 2007) are also subject to this limitation, but are at least comparable. Further research is required to assess the true size distribution of $\mathrm{rBC}$ deposition to the Devon ice cap and other Arctic sites.

Uncertainties in the DV99.1 age model are primarily due to the potential identification error of the Laki 1783 layer in the EC profile, and to interannual variations in $\dot{A}$ at the ice-coring site. The relationship between true depth and ice- 

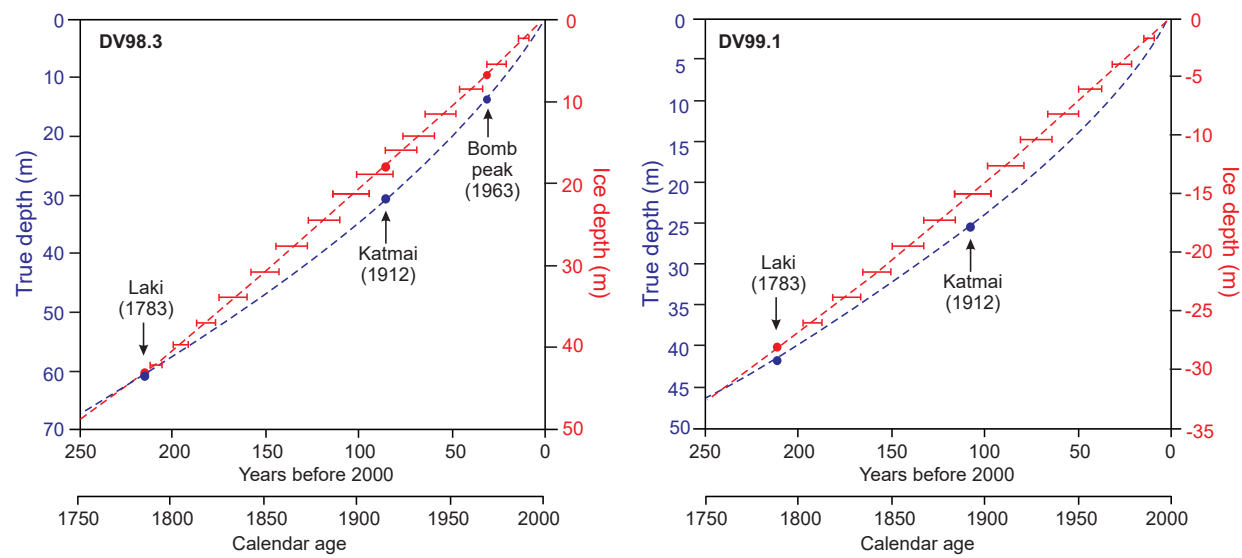

Figure 2. Age models for parts of the DV98.3 and DV99.1 cores from Devon ice cap. The error bars on the age curve relative to ice-equivalent depths (red) bracket the $95 \%$ confidence interval on the estimated age for discrete depths, as established from Monte Carlo simulations (see text).

equivalent depth is nearly linear in the DV99.1 core down to $48 \mathrm{~m}$, which suggests a steady firn densification rate over the corresponding time interval, with no signs of dynamically induced changes in the vertical strain rate. For the 1783 layer, we conservatively assumed a possible dating error of \pm 5 years, corresponding to a depth registration error of $\sim \pm 1 \mathrm{~m}$ at the $42.6 \mathrm{~m}$ EC peak. The interannual variability in $\dot{A}$ was estimated from an array of shallow cores (Colgan and Sharp, 2008) and from winter mass balance measurements since 1961 (data available through the World Glacier Monitoring Service). This information was used in a Monte Carlo simulation in MATLAB ${ }^{\mathrm{TM}}$ with 1000 realizations to compute confidence limits (CL) on the decadally averaged rBC data. Briefly, a constrained random walk algorithm was used to estimate the probabilistic distribution of the true age at any depth in the core from the surface down to the Laki 1783 layer (Kinnard et al., 2006). Interannual variations in $\dot{A}$ were considered to behave as a stationary, autoregressive blue noise process with a lag-one serial autocorrelation coefficient of -0.5 to -0.3 , based on empirical data presented by Fisher et al. (1985). Thus, a population of 1000 alternative age models was generated. From each of these, 10-year averages of the $\mathrm{rBC}$ data were computed, and $95 \% \mathrm{CL}$ were calculated for the geometric mean $\mathrm{rBC}$ concentration in each decade (Fig. S10). Expressed as a coefficient of variation $(\mathrm{CV})$, the estimated uncertainty on the decadally averaged rBC concentrations that arise from age model errors varies from 3\%-23\% (median 6\%), depending on the decade considered.

The spatial variability of $\mathrm{BC}$ deposition on Canadian Arctic ice caps is unknown. An estimate for Devon ice cap can be made from major ion analyses on shallow cores (Colgan and Sharp, 2008; Fig. 1). In these cores, the spatial CV on the annual $\mathrm{SO}_{4}^{2-}$ deposition averages $42 \%$ (range $17 \%-100 \%$ ) over a period of $\sim 40$ years. Here, we make the assumption that the deposition of $\mathrm{BC}$ on Devon ice cap shares the same spatial variability as $\mathrm{SO}_{4}^{2-}$, an aerosol species which, like $\mathrm{BC}$ but unlike others such as nitrate $\left(\mathrm{NO}_{3}^{-}\right)$, is not subject to reemission from snow to air. While the spatial variability may be large on an annual basis, Monte Carlo simulation results show that averaging the $\mathrm{rBC}$ data over 10-year intervals reduces its effect on the geometric mean $\mathrm{rBC}$ uncertainty to a few percent (CV) in any decade (Fig. S10). The potential impact of post-depositional modifications in the $\mathrm{rBC}$ record is discussed in Sect. 4.2.

\section{Results and discussion}

\subsection{The DV99.1 record of $\mathrm{rBC}$}

The depth profile of $\mathrm{rBC}$ measured in the DV99.1 core is shown in Fig. 3. The probability distribution of $\mathrm{rBC}$ concentrations is approximately log-normal (Fig. S11); therefore, we use both the arithmetic and geometric means ( $\mu$, $\mu_{\mathrm{g}}$ ), as descriptive metrics for these data. Over the entire core length, rBC concentrations average $1.8 \pm 3.9 \mathrm{ng} \mathrm{g}^{-1}$ $\left(\mu_{\mathrm{g}}=0.8 \mathrm{ng} \mathrm{g}^{-1}\right)$ with a maximum of $74.0 \mathrm{ng} \mathrm{g}^{-1}$. The mean $\mathrm{rBC}$ concentration is approximately constant between 42 and $15 \mathrm{~m}$ depths, and decreases gradually at shallower depths to reach $\sim 1.0 \mathrm{ng} \mathrm{g}^{-1}\left(\mu_{\mathrm{g}}=0.5 \mathrm{ng} \mathrm{g}^{-1}\right)$ in the uppermost meter of core. Concentrations below $42 \mathrm{~m}$ show a comparatively larger variability and a greater range of values (Fig. S12).

In Greenland cores, rBC deposition rose in the 1880s, peaked in the 1910s-1920s, and decreased thereafter (McConnell et al., 2007), in step with historical changes in coal burning BC emissions from North America and Europe (Novakov et al., 2003; Bond et al., 2007; Lamarque et al., 2010). In south-central Greenland, the early 20th century rise in rBC and nssS was also accompanied by increased deposi- 

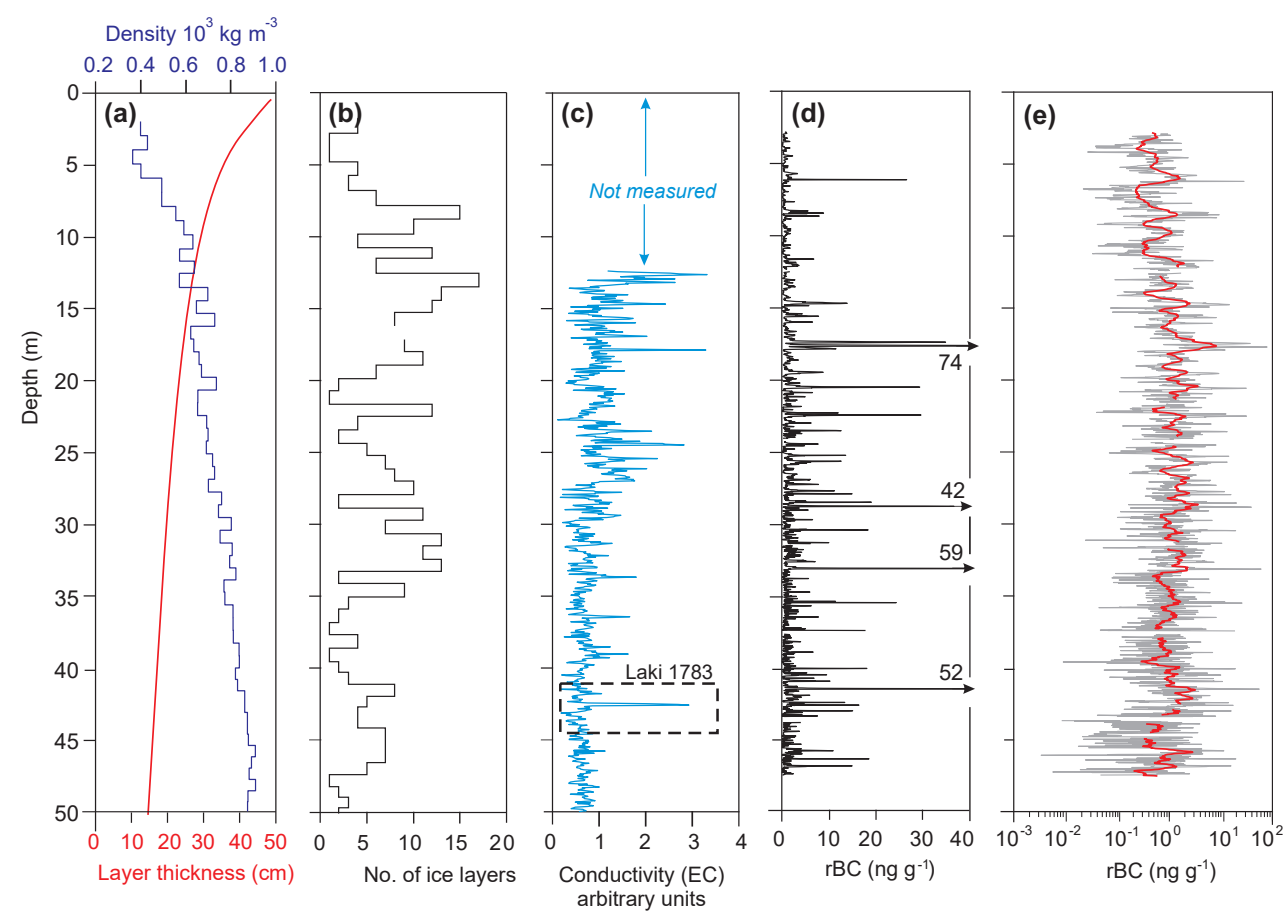

Figure 3. Profiles of physical properties and $\mathrm{rBC}$ in the top $48-50 \mathrm{~m}$ of the DV99.1 ice core. (a) Firn density and estimated mean annual layer thickness. (b) Frequency of discrete ice layers ( $>3 \mathrm{~mm}$ thick) per core section. (c) Solid-state electrical conductivity (EC) profile of the core from 12.8 to $50 \mathrm{~m}$ depth, smoothed to a vertical resolution of $\sim 1 \mathrm{~cm}$. The EC peak attributed to acidic fallout from the Laki 1783 eruption is labeled. (d, e) rBC concentrations plotted on linear and log scales. The bold red line is a 50-point $(\sim 1 \mathrm{~m})$ moving average.

tion of $\mathrm{Pb}$ and other trace metals (McConnell and Edwards, 2008). Measurements from the DV98.3 and DV2000 ice cores (Fig. 4) show that Devon ice cap also experienced increased atmospheric deposition of $\mathrm{SO}_{4}^{2-}$ and $\mathrm{Pb}$ and during the 20th century, peaking between the 1960s and 1980s. This was followed by a decline, consistent with trends in midlatitude anthropogenic emissions from fossil fuel combustion. However, unlike in Greenland, the DV99.1 core shows no large, sustained increase in $\mathrm{rBC}$ concentration concomitant with that of $\mathrm{SO}_{4}^{2-}$ or $\mathrm{Pb}$. There is a modest rise in mean $\mathrm{rBC}$ concentrations from the early 1800 s to the mid-20th century, but it is much more gradual and of lesser magnitude than the $\mathrm{rBC}$ rise observed in ice-core records from Greenland; the relative timing and the magnitude of these increases also differ between core sites (Figs. 5 and 6). In the DV99.1 ice core, the highest mean rBC concentrations for the 20th century occur in the decade from 1960 to $70\left(\mu=4.7 \mathrm{ng} \mathrm{g}^{-1}\right.$, $\mu_{\mathrm{g}}=1.7 \mathrm{ng} \mathrm{g}^{-1}$ ), but these are not unprecedented, and comparable mean concentrations occur in the earliest part of the record, in the decade from 1780 to 1790 (Fig. S12).

The DV99.1 record also shows a pronounced decline in rBC concentration in the late 20th century, but it occurs after the 1960s, which is later than in most Greenland cores, except at Humboldt (Figs. 5 and 6). However, this difference in timing could be due to uncertainties in the DV99.1 chronology compared to that of annually dated Greenland cores. The DV99.1 mean rBC concentrations over the period from 1960 to $1990\left(\mu=0.6-1.0 \mathrm{ng} \mathrm{g}^{-1} ; \mu_{\mathrm{g}}=0.3-\right.$ $0.5 \mathrm{ng} \mathrm{g}^{-1}$ ) are lower than in the early modern industrial period (early 19th century; $\mu=1.0-3.0 \mathrm{ng} \mathrm{g}^{-1} ; \mu_{\mathrm{g}}=0.7-$ $\left.1.6 \mathrm{ng} \mathrm{g}^{-1}\right)$. The only Greenland ice core in which a similar situation occurs is from the ACT2 site $\left(66^{\circ} \mathrm{N}\right.$, Fig. 5). Neither the winter mass balance measurements, nor the reconstructed interannual changes in $\dot{A}$ on Devon ice cap (Colgan and Sharp, 2008) show any sustained long-term trend since the early 1960s; therefore, the decrease in the rBC concentration in the DV99.1 core during this period can not be ascribed to changing precipitation rates on the ice cap. It seems more likely that the decrease is at least in part due to a declining burden of atmospheric BC in the Canadian High Arctic since the 1960s (Gong et al., 2010). However, there are several methodological, site-specific and regional-scale factors that must be taken into account when interpreting the DV99.1 $\mathrm{rBC}$ record. These are discussed below.

\subsection{Methodological and site-specific factors}

Observations of atmospheric BC at Alert on Ellesmere Island $\left(82^{\circ} \mathrm{N}\right.$, Fig. 1) show a seasonal cycle with airborne concentrations peaking during winter and spring months (December-March) and declining to their minimum in summer and early autumn months (June-September) (Gong et al., 2010). Most BC deposition in snow is thought to occur 

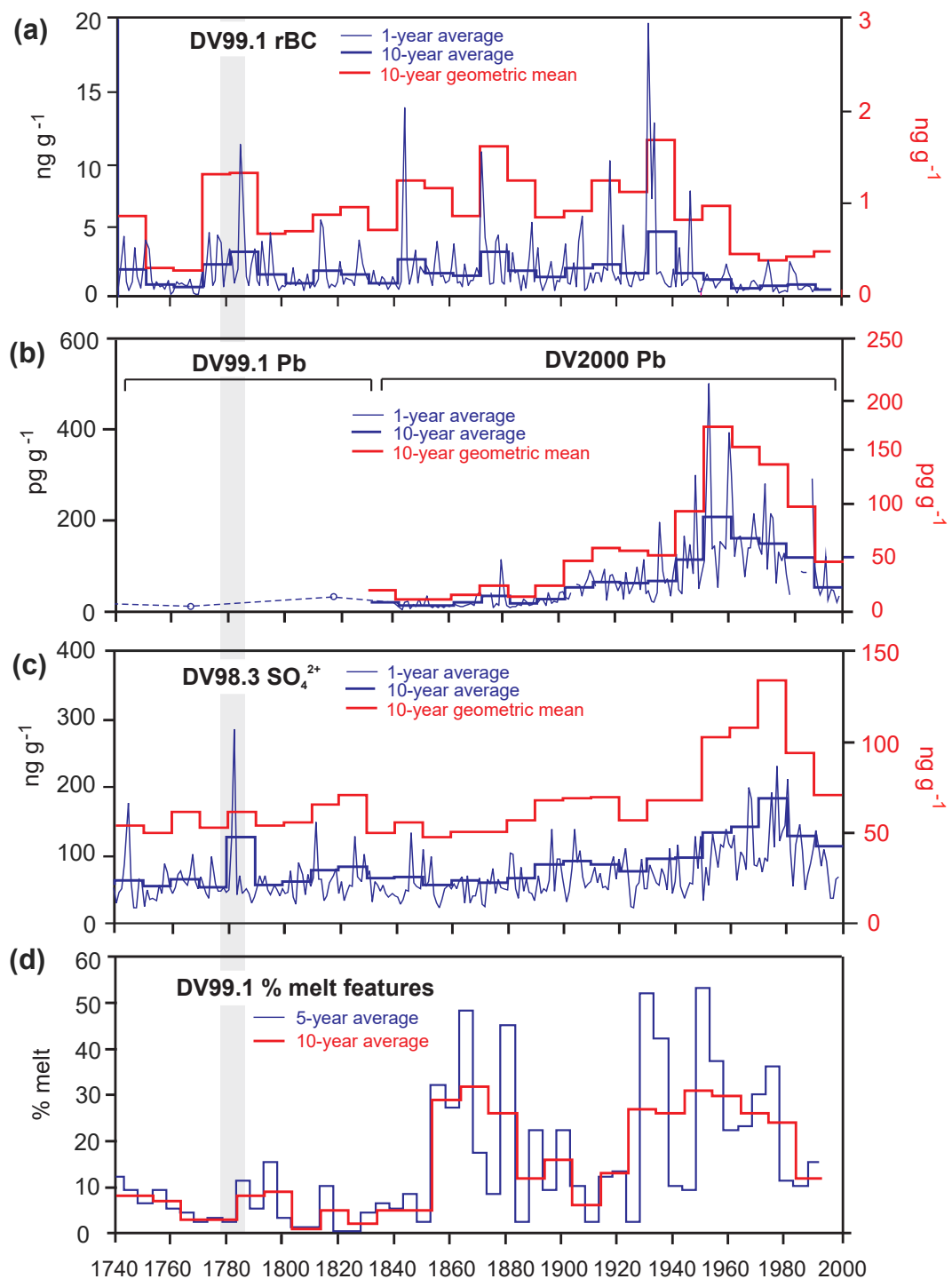

Figure 4. Environmental changes on Devon ice cap, 1740-1999, recorded in three cores from the summit region (DV98.3, DV99.1, and DV2000). (a) rBC concentrations in the DV99.1 core; (b) Pb concentrations in the DV99.1 core ( 1740-1840) and DV2000 core (18402000); (c) $\mathrm{SO}_{4}^{2-}$ in the DV98.3 core; and (d) volumetric percentage of icy melt features in the DV99.1 core due to surface summer melt. Data are presented in $\sim 1$-year, 5-year and/or 10-year averages. For panels (a) to (c), 10-year geometric mean values of the data are also plotted in red on separate scales (right). The shaded grey bar identifies the Laki 1783 isochron used to correlate the different cores. The width of the bar denotes the maximum dating uncertainty at the corresponding depths in these cores. The $\mathrm{Pb}$ data are from Shotyk et al. (2005) and Zheng et al. (2007), the $\mathrm{SO}_{4}^{2-}$ data are from Kinnard et al. (2006), and the melt feature data are from Fisher et al. (2012).

in spring and summer, when increased cloudiness promotes in-cloud scavenging and wet deposition of particles containing BC (Garrett et al., 2011; Browse et al., 2012; Shen et al., 2017). In the interior of the Greenland ice sheet, the seasonal cycle of $\mathrm{BC}$ deposition is well-preserved in snow and firn layers (e.g., McConnell et al., 2007). This is not the case at the DV99.1 core site on Devon Island. Even in the uppermost part of the core, where some seasonal $\delta^{18} \mathrm{O}$ variations can be detected, there is no recognizable seasonal pattern of $\mathrm{rBC}$ concentration peaks (Fig. S13). This is likely the result of the combined effects of wind scouring/mixing of surface snow (as described earlier) and of summer surface melt. Therefore, the question arises as to whether such processes could also have obliterated or masked a 20th century anthropogenic signal in the DV99.1 $\mathrm{rBC}$ record.

The seasonally resolved ice-core record from the D4 site in Greenland $\left(71^{\circ} \mathrm{N}\right.$; Fig. 5) shows that during the historical period of enhanced anthropogenic BC pollution in the Arctic, from the late 19th to mid-20th centuries, rBC deposition increased in both summer and winter (McConnell et 


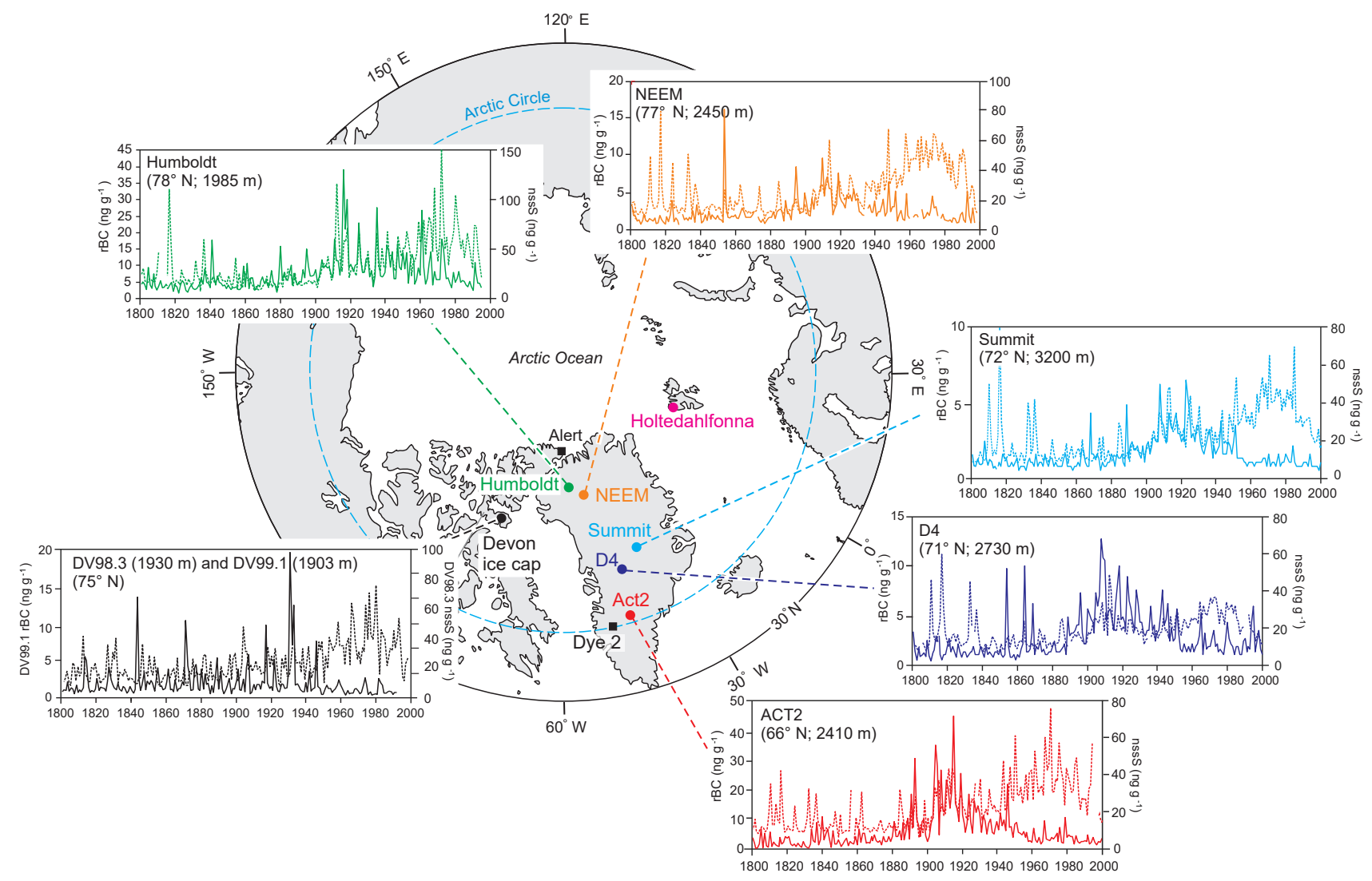

Figure 5. The record of atmospheric rBC and non-sea salt sulfur (nssS) deposition on Devon ice cap over the period from 1800 to 2000 compared with similar records developed at various sites in Greenland by identical or almost identical methods. Full lines are rBC; stippled lines are nssS. Data from Summit, D4, ACT2, and Humboldt are sourced from McConnell et al. (2007) and Koch et al. (2011), and data from NEEM are sourced from Zennaro et al. (2014) and Sigl et al. (2015). Also shown is the location of the ice-core record of elemental carbon deposition developed from Holtedahlfonna, Svalbard, by Ruppel et al. (2014), in addition to other sites (Alert, Dye 2) mentioned in the text.

al., 2007). If the Canadian High Arctic was impacted by airborne $\mathrm{BC}$ pollution in a similar way, one would expect to find a marked increase in $\mathrm{rBC}$ concentrations in the DV99.1 core during the early 20th century, even if winter snow layers were scoured away by wind. To verify this, we performed a simple simulation in which we generated synthetic time series of $\mathrm{rBC}$ deposition spanning the period from 1800 to 1990, with a seasonal cycle superimposed on baseline interdecadal variations similar to those observed in the Greenland D4 ice-core record. Winter rBC deposition peaks in the series were represented using a log-Gaussian function, and their amplitude was allowed to vary from year to year to produce a range of temporal variations comparable to, or lower than, that seen in the Greenland D4 core. Winter deposition peaks were then randomly truncated by $30 \%-60 \%$ (mean $45 \%$ ) to simulate the effects of wind scouring on the record, and 5-year running means were computed from the resulting data. Smoothing was used to simulate the effects of post- depositional snow layer mixing by wind. Results of these experiments show that even if the wintertime $\mathrm{rBC}$ deposition peaks between November and May were largely truncated by wind, the low-frequency baseline variation would still persist, and should be recognizable above the remaining interannual signal variance (Fig. 7). Therefore, it seems unlikely that wind scouring would completely obliterate this rBC signal in the DV99.1 record, unless the amplitude of the seasonal cycle of atmospheric BC deposition on Devon ice cap is much lower than observed at Alert or in Greenland (Gong et al., 2010; Massling et al., 2015).

Unlike much of central Greenland, the summit of Devon ice cap is subject to partial melting at the surface during summer months, and meltwater can percolate and refreeze into the underlying snow and firn to form infiltration ice features ("melt layers"). The volumetric percentage of melt layers in the DV99.1 core was measured by Fisher et al. (2012) as a proxy for past summer warmth. These data show that surface 

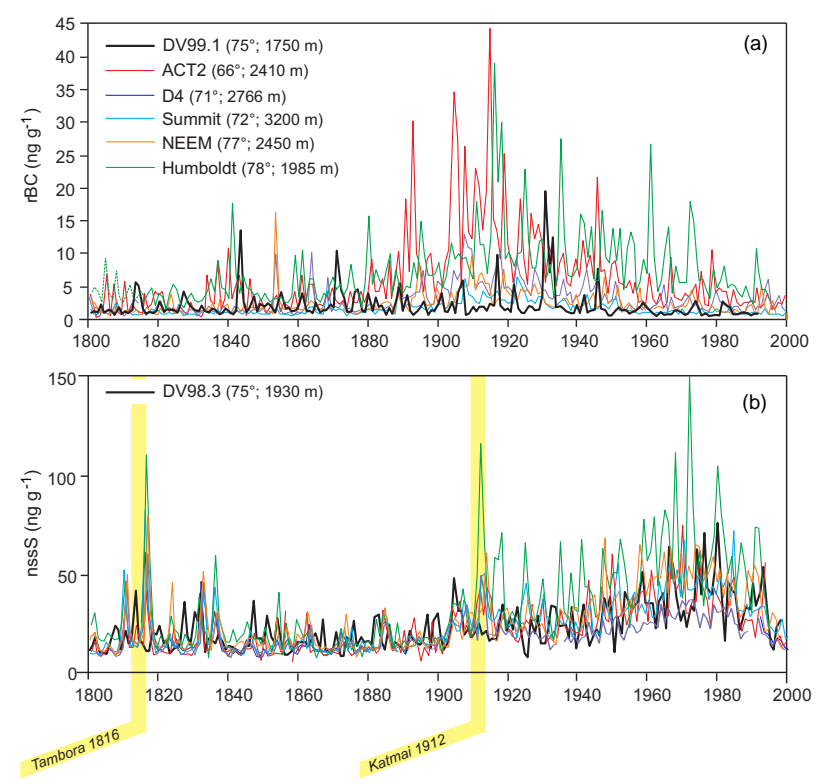

Figure 6. (a) The DV99.1 record of atmospheric $\mathrm{rBC}$ deposition since 1800 compared with other records developed from sites in Greenland identified in Fig. 5. All records are presented in 1-year averages. (b) As in (a) but for records of non-sea salt sulfur (nssS). Two volcanic eruption isochron used for correlation in the Greenland cores are highlighted.

melt rates at the coring site increased abruptly in the mid19th century following the end of the Little Ice Age cold interval, and have since averaged $22 \%$ (median 19\%), occasionally exceeding $50 \%$ in the 20th century (Fig. 4). The DV99.1 coring site is above the present-day upper limit of the superimposed zone ( $\sim 1400$ m a.s.l.; Gascon et al., 2013) and the firn there is $>60 \mathrm{~m}$ thick. Therefore, it is very unlikely that there is any net loss by runoff at this location: any meltwater produced in the summer must refreeze in the firn. However, even without net losses, one must consider whether meltwater percolation and refreezing could account for the limited variability in the DV99.1 $\mathrm{rBC}$ record during the 19 th and 20th centuries.

The post-depositional mobility of $\mathrm{BC}$ particles in melting snow is not well known, and likely depends on the hydrophobicity of these particles, which is influenced by the presence or absence of surface coatings, for example, with $\mathrm{SO}_{4}^{2-}$ (Liu et al., 2011, 2013). Doherty et al. (2013) investigated the vertical redistribution of $\mathrm{BC}$ and other light-absorbing particles in snow and firn near Dye $2\left(66^{\circ} \mathrm{N} ; \sim 2100 \mathrm{~m}\right.$ a.s.l.; Fig. 5) in a part of the Greenland ice sheet's percolation zone where melt layers $>10 \mathrm{~cm}$ thick are now commonly found (de la Peña et al., 2015; Machguth et al., 2016). Only very limited vertical redistribution of $\mathrm{BC}$ was observed in the snow and firn, and surface melt and percolation did not obliterate seasonal variations of $\mathrm{BC}$ in the firn stratigraphy. Doherty et al. (2013) attributed this result to the low scavenging effi-
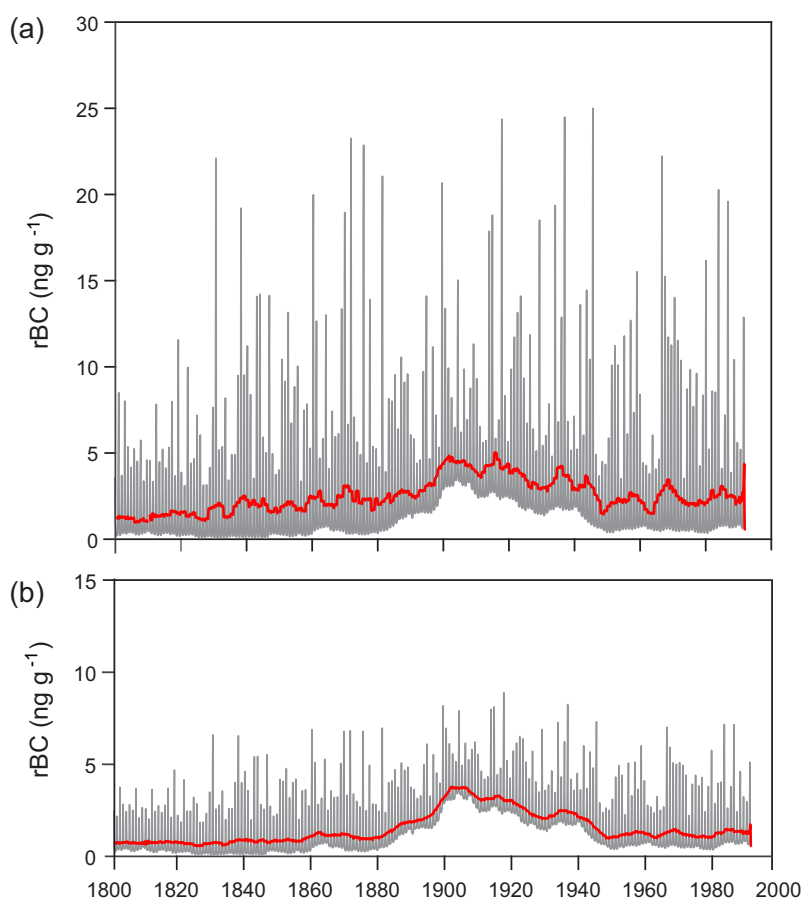

Figure 7. Simulation of the effects of wind scouring of snow on the preservation of an anthropogenic signal of $\mathrm{rBC}$ deposition in a synthetic ice-core times series of $\mathrm{rBC}$ spanning the period from 1800 to 1990 . (a) The synthetic series, with a pseudo-seasonal cycle superimposed on the interdecadal baseline trend observed in the Greenland D4 record (McConnell et al., 2007). (b) The synthetic series after randomly truncating the amplitude of all winter deposition peaks (November-March) by $30 \%-60 \%$. The bold red line in both panels is a 5-year running geometric mean.

ciency of these particles by meltwater $(\sim 20 \%-30 \%)$. At the DV99.1 site on Devon Island, ice layers $>10 \mathrm{~cm}$ are comparatively very rare, but $\dot{A}\left(0.14 \mathrm{~m} \mathrm{a}^{-1}\right)$ is only half of that in the Dye 2 area $\left(\sim 0.32 \mathrm{~m} \mathrm{a}^{-1}\right.$; Buchardt et al., 2012). Therefore, surface melt could mask some seasonal variations of $\mathrm{rBC}$ in the firn.

The depth at which meltwater could percolate in firn at the DV99.1 site is not precisely known over the time period covered in the $\mathrm{rBC}$ record. The thickness of the firn zone there $(>60 \mathrm{~m})$ is much greater than other locations, such as Lomonosovfonna summit, Svalbard $(\sim 25 \mathrm{~m}$; Kekonen et al., 2005). If we accept the estimated depth range of 0.5 $2 \mathrm{~m}$ for meltwater-induced relocation of water-soluble ions at Lomonosovfonna summit for 2000-2007 reported by Vega et al. (2016), then it is highly unlikely that the relocation of rBC particles could be deeper at the DV99.1 site. The summit of Devon ice cap is $\sim 650 \mathrm{~m}$ higher than the Lomonosovfonna summit (1250 ma.s.1.), has a much lower mean annual surface temperature $\left(-22^{\circ} \mathrm{C}\right.$, compared with $\sim-10$ to $-12^{\circ} \mathrm{C}$ at Lomonosovfonna; Ward van Pelt, personal communication, 2017), and the $10 \mathrm{~m}$ firn temperature on Devon 

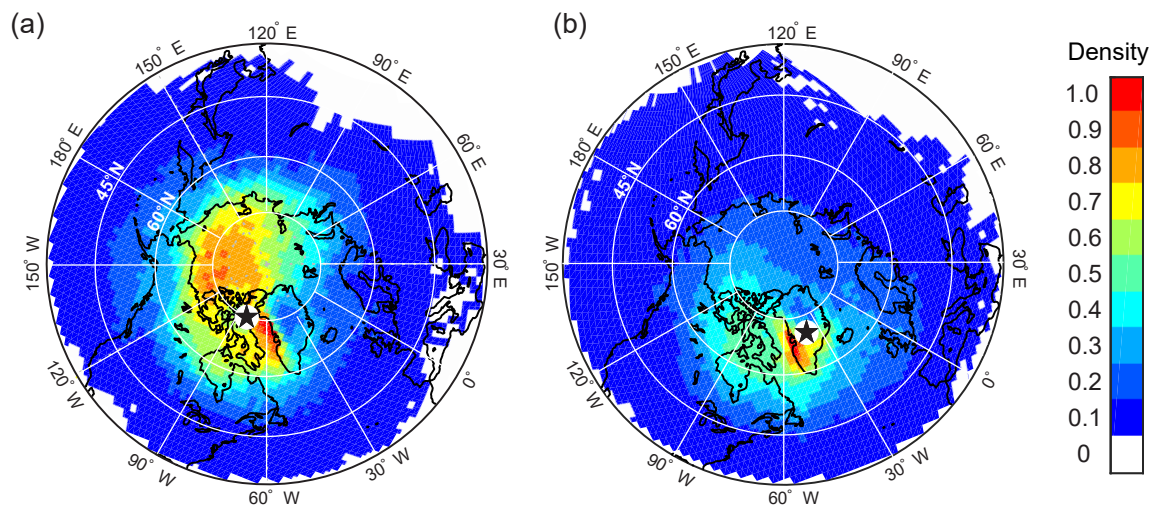

Figure 8. Maps of residence time probability for air arriving at (a) Devon ice cap and (b) Summit, Greenland over the period from 1948 to 1999, computed using HYSPLIT4. Air residence probability densities were normalized to a scale of 0-1, and were spatially detrended by multiplying the original residence time grids (in hours) by the distance between each grid point and the coring site. This effectively removes the concentric increase in probability density near the back-trajectory start point (Ashbaugh et al., 1985). The spatial resolution of the grid is $200 \times 200 \mathrm{~km}$.

ice cap summit was $<-15^{\circ} \mathrm{C}$ (Bezeau et al., 2013), in 2012, while at Lomonosovfonna it was -2 to $-3^{\circ} \mathrm{C}$ (van de Waal et al., 2002), in 1997. Attempts were also made to quantify post-depositional deposition of ions and/or particles by melt/percolation on Penny ice cap on Baffin Island $\left(66^{\circ} \mathrm{N}\right.$; Grumet et al., 1998; Zdanowicz et al., 1998), where estimated summer melt rates over the last 150 years are much higher (40\%-100\%) than at the DV99.1 site (Zdanowicz et al., 2012). On Penny ice cap during the mid-1990s, ions and particles were estimated to be redistributed over depths of 3-5 $\mathrm{m}$. Therefore, a plausible, conservative estimate of the maximum melt-induced relocation depth at the DV99.1 site for the time period of interest might be $3 \mathrm{~m}$ (firn depth). With a mean accumulation rate of $0.16 \mathrm{~m} \mathrm{H}_{2} \mathrm{O} \mathrm{a}^{-1}$ at the site, soluble impurities could be offset by meltwater percolation in the core by 5-8 years relative to their true depositional depth/age, and probably less for BC particles given their hydrophobicity. In this paper, we focus on interdecadal variations in rBC concentrations. At such a time-averaging window length, the effect of impurity relocation by melt should largely even out.

However, there is another consideration. Unlike in the Doherty et al. (2013) study, rBC concentrations in the DV99.1 core were measured by SP2, and the detection efficiency of this method for BC in liquid samples depends on the type of nebulizer used for inflow. As previously mentioned, Schwarz et al. (2012) and Wendl et al. (2014) showed that the relative aerosolization efficiency of $\mathrm{rBC}$ by the U5000AT ultrasonic nebulizer used in the analysis of the DV99.1 core drops rapidly for particles with a volume-equivalent diameter $>500 \mathrm{~nm}(\sim 10 \%$ efficiency at a volume-equivalent diameter of $600 \mathrm{~nm}$ ). Coagulation and agglomeration is known to increase the size of $\mathrm{BC}$ particles during thaw and refreezing of snow (Schwarz et al., 2013), which raises the possibility that the SP2 may underestimate the true mass concentration of BC particles in those parts of the DV99.1 that contain icy layers (Fig. 3).

To verify this, we examined the probability distribution of rBC particle mass in sections of the DV99.1 ice core with different percentages of melt layers. We compared core sections from depths between 37 and $38 \mathrm{~m}$ (corresponding to the time interval $\sim 1803-1814$ ) which only had $1 \%$ melt layers, with sections from depths between 13 and $16 \mathrm{~m}$ (time interval 1943-1963), which had up to $53 \%$ melt features (min. $9 \%$ ); we found no significant differences between these core sections (Fig. S14). If rBC particles had coagulated to form larger clusters in sections of core where a lot of percolating meltwater refroze, the probability distribution or $\mathrm{rBC}$ mass in these sections should be positively skewed relative to that in core sections not impacted by meltwater, but our data show no evidence of this. While it remains possible that melt-refreezing may have contributed to masking some of the historical variations in atmospheric $\mathrm{BC}$ deposition at the DV99.1 site, it seems unlikely, based on available evidence, that this factor alone could account for the low rBC concentrations in the DV99.1 core, when compared to Greenland records analyzed using the same methods.

Some of the central and northern Greenland sites (e.g., Summit, NEEM) from which ice-core $\mathrm{rBC}$ records were developed by the SP2 method (Fig. 5) experience less surface melt than Devon ice cap, and BC particles in firn at these sites are probably largely unaffected by post-depositional coagulation. Other coring sites located in southern Greenland (ACT2, D4) or at lower elevations (Humboldt) may experience some surface melt and refreezing in summer, but statistics on ice layer frequency at these sites are unpublished, so this cannot be verified. 


\subsection{Regional-scale factors}

Other reasons for the differences between the DV99.1 and Greenland $\mathrm{rBC}$ records (Figs. 6 and 7) may be found in the atmospheric transport paths that deliver BC to the Canadian High Arctic, relative to Greenland. Shindell et al. (2008) used multiple atmospheric transport models to investigate the sensitivity of near-surface airborne $\mathrm{BC}$ concentrations in the Arctic to regional anthropogenic emissions. They found that Europe and North America likely contribute equally to BC deposition over Greenland, whereas the central and Russian sectors of the Arctic are more impacted by European emissions. Atmospheric BC in the Canadian High Arctic may be affected by both European and North American emissions, but the region is expected to be less sensitive to changes in these emissions compared to other parts of the Arctic, partly because it is very remote from all BC source regions (Shindell et al., 2008; their Figs. 9 and 10).

Sharma et al. (2006) and Huang et al. (2010) used air backtrajectory analyses to investigate the probable source regions of $\mathrm{BC}$ detected at Alert in winter and spring, and identified Russia and Europe as dominant, followed by North America. The summit of Devon ice cap is $1000 \mathrm{~km}$ further south and $\sim 1.9 \mathrm{~km}$ higher; thus, it could be affected by a different mix of BC source contributions than Alert. To verify this, and also to contrast the situations of Devon ice cap and Greenland, we computed ensemble 10-day air back-trajectories from both Devon ice cap summit and from Summit, Greenland, using the Hybrid Single Particle Lagrangian Integrated Trajectory model (HYSPLIT v.4) of the NOAA Air Resources Laboratory (Draxler and Hess, 2014; Stein et al., 2015). As input, we used meteorological fields of the NCEP-NCAR 50-year reanalysis product, which are available on a global $2.5 \times 2.5^{\circ}$ grid at 6-hourly temporal resolution (Kistler et al., 2001). Back trajectories starting daily at 12:00 UTC were computed over the period from 1948 to 1999 . However, unlike Sharma et al. (2006) and Huang et al. (2010), we did not use trajectory clustering, as results are highly sensitive to the quality and density of meteorological data coverage used in trajectory computations, and to the arrival height of trajectories (i.e., starting point of back trajectories; Kassomenos et al., 2010; Su et al., 2015). Instead, we computed probability density maps or air parcel residence time from all combined trajectories over an equal area grid with $200 \times 200 \mathrm{~km}$ resolution, following a methodology analogous to that of Miller et al. (2002).

Results (Fig. 8) show that for 10-day transport periods, air parcels arriving at Summit, Greenland, are more commonly advected from the south-southwest than from other directions, and frequently reach central Greenland after transiting over the North Atlantic, consistent with earlier findings by McConnell et al. (2007; their Fig. S1). In contrast, air that reaches the summit of Devon ice cap more comes frequently from the west-northwest, and transits over the Arctic Ocean, which agrees with findings from analyses of low- (a)

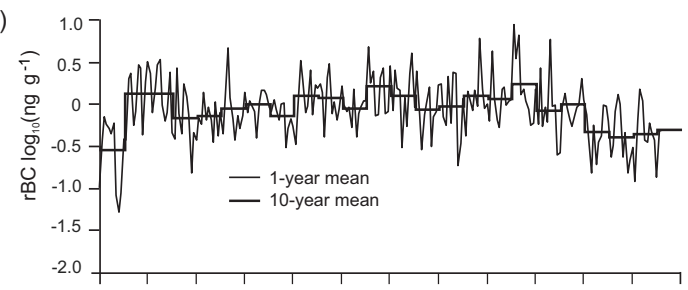

(b)

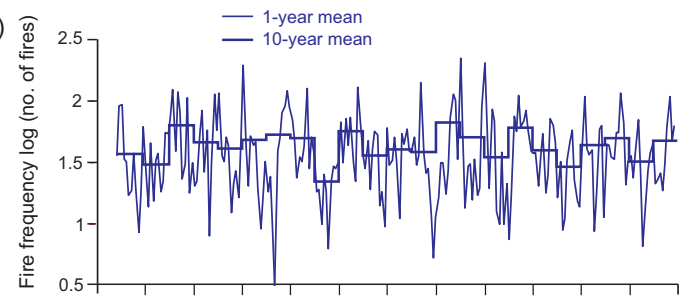

(c)

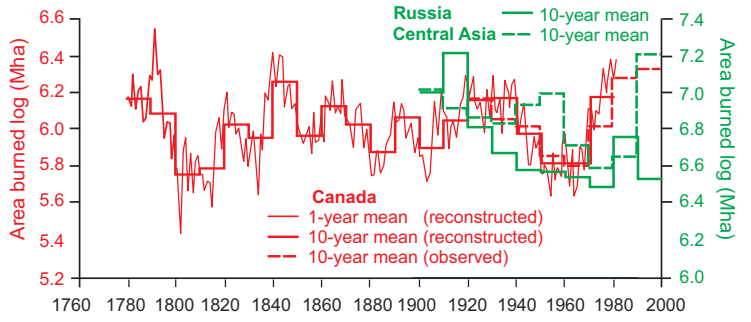

Figure 9. (a) Historical variations in $\mathrm{rBC}$ concentration in the DV99.1 core, 1760-1992, compared with reconstructed historical trends in (b) fire frequency in the eastern boreal forest region of Canada (Girardin et al., 2006), and (c) burned area across northern Canada (Girardin, 2007) and in the boreal and grassland regions of Russia and central Asia (Mouillot and Field, 2005). All data were log-transformed to facilitate visual comparisons.

level air transport to Devon ice cap by Colgan and Sharp (2008) for the period from 1979 to 2003. Therefore, it is likely that a large part of BC transported to Devon ice cap is from regional emission sources located in northwestern North America and/or in the central or eastern parts of Eurasia.

Smoke plumes from forest or grassland fires, natural or provoked, can reach the Arctic and contribute to $\mathrm{BC}$ pollution, particularly during summer (Stohl et al., 2006; Paris et al., 2009; Warnecke et al., 2009; Quennehen et al., 2012; Zennaro et al., 2014; Hall and Loboda, 2017). Backtrajectory analyses of BB aerosols detected at Eureka on Ellesmere Island $\left(80^{\circ} \mathrm{N}\right.$; Fig. 1) indicate (as anticipated) that boreal forest/grassland regions of Russia and Canada are the dominant source regions for these long-range plume transport events, followed by north-central USA and Alaska (Viatte et al., 2015). To investigate the impact of forest/grassland fire emissions on BC deposition to Devon ice cap, we compared the DV99.1 $\mathrm{rBC}$ record with reconstructed variations in fire frequency and/or burned area across Canada and Russia during the 19th and/or 20th centuries (Fig. 9; data from Girardin, 2007; Girardin and Sauchyn, 2008; Girardin et al., 2006; and Mouillot and Field, 2005). On an interdecadal 
timescale, no statistically meaningful correlations $(p<0.05)$ could be identified between the DV99.1 $\mathrm{rBC}$ record and the fire histories. If fire emissions contribute to $\mathrm{BC}$ deposition on Devon ice cap, these contributions are either too small and/or mixed in the DV99.1 record to be correlated with variations in fire frequency or burned area in the source regions.

Aerosol species such as $\mathrm{K}^{+}$or $\mathrm{NH}_{4}^{+}$are commonly associated with $\mathrm{BB}$ emissions, and are often used as BB tracers in polar snow (Simoneit, 2002; Legrand et al., 2016). Cheng (2014) identified sectors of south-central Russia and Kazakhstan as source regions for both $\mathrm{BC}$ and $\mathrm{K}^{+}$aerosols transported to Alert between 2000 and 2002. However, we did not find any significant correlations $(p<0.05)$ between interdecadal variations of $\mathrm{rBC}$ in the DV99.1 core and either $\left(\mathrm{K}^{+}\right)_{\mathrm{BB}}$ or $\mathrm{NH}_{4}^{+}$in the DV98.3 record (Fig. S15). Whatever contributions $\mathrm{BB}$ emissions make to $\left(\mathrm{K}^{+}\right)_{\mathrm{BB}}$ or $\mathrm{NH}_{4}^{+}$deposition on Devon ice cap, these do not directly covary with BC deposition, possibly due to the different post-depositional relocation of these impurities in the DV98.3 and DV99.1 cores, and mixing from multiple emission sources. For example, ammonia $\left(\mathrm{NH}_{3}\right)$ emissions from seabird colonies near Baffin Bay may be a larger regional source of $\mathrm{NH}_{4}^{+}$to Devon ice cap than distant wildfires (Wentworth et al., 2016).

\subsection{Atmospheric BC deposition rates}

In $90 \%$ of the analyzed DV99.1 core, rBC concentrations are $<3 \mathrm{ng} \mathrm{g}^{-1}$, and in the uppermost section of the core (depths 3-4 m), they are mostly $\leq 1 \mathrm{ng} \mathrm{g}^{-1}$. These concentrations are very low compared with the $8-14 \mathrm{ng} \mathrm{g}^{-1}$ reported by Doherty et al. (2010) for seasonal snow sampled across the Canadian Arctic in 2009. Part of the apparent discrepancy may be due to differences in analytical methods: the BC concentrations in snow reported by Doherty et al. (2010) were measured using a spectrophotometric technique which tends to yield larger mass concentrations relative to the SP2 method (Schwarz et al., 2012). Also, as previously stated, rBC levels measured in the DV99.1 core may underestimate actual deposition due to wind scouring of winter snow. Atmospheric BC deposition over the summit region of Devon ice cap could also be lower than near sea level, where most of Doherty et al.'s (2010) samples were obtained, because most of the ice cap's accumulation area ( $\geq \sim 1150 \mathrm{~m}$ a.s.l. $)$ is above the typical altitude range of low-level Arctic stratocumulus cloud decks which promote aerosol scavenging (Browse et al., 2012).

Taking the aforementioned uncertainties into account, we estimated the average late 20th century atmospheric flux of $\mathrm{rBC}\left(F_{\mathrm{rBC}}\right)$ over the summit region of Devon ice cap using measurements of $\mathrm{rBC}$ concentrations in the DV99.1 core for the period from 1963 to 1990 , and data on spatial and temporal variations of $\dot{A}$ from Colgan and Sharp (2008) and from winter mass balance surveys carried out over the ice cap since the early 1960s. The period from 1963 to 1990 was selected because the 1963 radioactive layer in Devon ice cap firn provides a reference level to constrain estimates of $\dot{A}$ (Colgan and Sharp, 2008). Our calculations yield a mean $F_{\mathrm{rBC}}$ of $0.2 \pm 0.1 \mathrm{mg} \mathrm{m}^{-2} \mathrm{a}^{-1}$. If $\mu_{\mathrm{g}}$, rather than $\mu$, is used to estimate average $\mathrm{rBC}$ concentrations, the estimated $F_{\mathrm{rBC}}$ is slightly lower $\left(0.1 \mathrm{mg} \mathrm{m}^{-2} \mathrm{a}^{-1}\right)$. Furthermore, if the measured concentrations of $\mathrm{rBC}$ are assumed to be underestimated by $60 \%-80 \%$ due to wind scouring of winter snow layers and/or inadequate detection by the SP2 instrument, the adjusted figures for $F_{\mathrm{rBC}}$ are only slightly higher, ranging between 0.2 and $0.3 \mathrm{mg} \mathrm{m}^{-2} \mathrm{a}^{-1}$.

These estimates are at the low end of the measured net rBC deposition rates in Greenland ice cores between the early 1960 s and late 1990 s, which vary from $\sim 0.1$ to $\sim$ $2.3 \mathrm{mg} \mathrm{m}^{-2} \mathrm{a}^{-1}$ (Lee et al., 2013; see also Fig. S16). Compared with most of central and southern Greenland, the summit region of Devon ice cap experiences low snow accumulation rates $\left(0.17-0.25 \mathrm{~m} \mathrm{H}_{2} \mathrm{O} \mathrm{a}^{-1}\right.$, or $\leq 0.31 \mathrm{~m} \mathrm{a}^{-1}$ in ice equivalent; Colgan and Sharp, 2008), and this probably accounts, at least in part, for the lower $\mathrm{rBC}$ accumulation rates there, given the important role of precipitation scavenging in controlling atmospheric BC deposition in the Arctic (Garrett et al., 2011; Browse et al., 2012). Other reasons for the differences in $\mathrm{rBC}$ accumulation between Devon ice cap and Greenland may be found in the predominant patterns of air transport trajectories from source regions, as previously discussed.

\section{Summary and conclusions}

We developed a $>250$-year time series of atmospheric $\mathrm{rBC}$ deposition from Devon ice cap spanning the years $\sim 1735$ 1992. The rBC ice-core record (core DV99.1) is the first from the Canadian Arctic, and supplements existing ice-core records of $\mathrm{rBC}$ from Greenland developed using the same analytical methods. The DV99.1 record differs from the Greenland records in that it only shows a very modest and gradual rise in $\mathrm{rBC}$ deposition through the 19th and early 20th century, unlike most Greenland ice cores, in which there are large, well-defined rises from 1880 to the 1990 s, peaking in the 1910s. This rise was attributed to BC emissions from coal combustion, which also emitted $\mathrm{SO}_{2}$ and trace metals such as $\mathrm{Pb}$ (McConnell et al., 2007). Ice cores from Devon ice cap (DV98.3, DV2000) show that the deposition of $\mathrm{SO}_{4}^{2-}$ and $\mathrm{Pb}$ also increased there during the 20th century, although the DV99.1 core shows no concomitant rise in $\mathrm{rBC}$.

We suggest that differences between the DV99.1 and the Greenland $\mathrm{rBC}$ records are due to a combination of methodological, site-specific, and regional-scale factors. The DV99.1 coring site is subject to summer melt-freeze cycles, and this may lead to some underestimation of true rBC concentrations by the SP2 method. There is also evidence of wind scouring of snow at the site, which may lessen the amplitude and resolution of historical variations in BC deposition recorded in the core. Air back-trajectory analyses 
suggest that, compared to Greenland, BC deposition on Devon ice cap is less sensitive to BC emissions from the North Atlantic sector (eastern North America and western Europe) than Greenland is. We hypothesize that BC aerosols reaching Devon ice cap more frequently originate from northcentral/northwestern North America, and/or from Russia and central Asia. The relatively long transport trajectories over the Arctic Ocean allow for greater atmospheric mixing and deposition of aerosols to occur during transit, which obscures source-receptor relationships. If correct, this interpretation implies that historical trends in BC deposition over the Arctic, and the resulting albedo-climate forcing, are likely subject to large spatial variability, even over the relatively short distance between Devon Island and Greenland. This variability, which is probably linked to differences in BC aerosol transport patterns and atmospheric residence time (Bauer et al., 2013), must be accounted for when attempting to model the impact of past and future BC emission trends on the Arctic climate system.

This study also underscores the challenges of interpreting records of aerosol deposition developed from firn or ice cores drilled on small ice caps or glaciers, where local topographic and climatological effects can impact the preservation of atmospheric signals, when compared with the central regions of large ice sheets. A limitation of our study stems from the fact that the DV99.1 record of $\mathrm{rBC}$ deposition is from a different site than records of other aerosol species $\left(\mathrm{SO}_{4}^{2-}, \mathrm{Pb}\right)$ previously obtained from Devon ice cap summit. To verify our interpretation of the DV99.1 rBC record, a new core should be drilled from the ice cap summit, or from another ice cap less affected by wind scouring and melt-freeze effects (e.g., on northern Ellesmere Island), and on which co-registered measurements of $\mathrm{rBC}$ and other aerosols could be made. This is particularly important when one considers the large amount of spatial variability inherent in ice-core records, even in areas of optimal preservation (e.g., Gfeller et al., 2014).

Data availability. The raw $\mathrm{rBC}$ concentration data from the DV99.1 core, as well as 1-year and 10-year averages of the time series used to produce the figures in this paper, are available for download in ASCII text format through the Canadian Polar Data Catalogue: https://www.polardata.ca/.

\section{The Supplement related to this article is available online at https://doi.org/10.5194/acp-18-12345-2018- supplement.}

Author contributions. BCP, RE, and CMZ designed the study. BCP, $\mathrm{RE}, \mathrm{CMH}$, and WF processed the core and conducted the $\mathrm{rBC}$ measurements. CK provided air back-trajectory analyses. DF provided information on ice-core age-depth models. CMZ wrote the manuscript, and all co-authors contributed to and reviewed the manuscript.

Competing interests. The authors declare that they have no conflict of interest.

Acknowledgements. The recovery of the DV99.1 ice core was supported by the Geological Survey of Canada and the Polar Continental Shelf Project (Natural Resources Canada). Analysis of the core was funded by Curtin University (Curtin Research Fellowship to R. Edwards, no. RES-SE-DAP-AW-47679-1), and by an Australian Endeavour Research Fellowship (no. ERF_PDR_3051_2012) awarded to BCP. Nicole Schaffer (Univ. of Ottawa) assisted with some of the illustrations. Insightful comments by three anonymous reviewers greatly contributed to improving earlier versions of this manuscript.

Edited by: Ari Laaksonen

Reviewed by: three anonymous referees

\section{References}

AMAP: The Impact of Black Carbon on Arctic Climate, Oslo: Arctic Monitoring and Assessment Programme (AMAP), 72 pp., 2011.

AMAP: Arctic Climate Issues 2015: Short-Lived Climate Pollutants: Summary for Policy-Makers, Oslo: Arctic Monitoring and Assessment Programme (AMAP), 16 pp., 2015.

Ashbaugh, L. L., Malm, W. C., and Sadeh, W. Z.: A residence time probability analysis of sulfur concentrations at Grand Canyon National Park, Atmos. Environ.,19, 1263-1270, https://doi.org/10.1016/0004-6981(85)90256-2, 1985.

Bauer, S. E., Bausch, A., Makarenko, L., Tsigaridis, K., Xu, B., Edwards, R., Bisiaux, M., and McConnell, J.: Historical and future black carbon deposition on the three ice caps: Ice-core measurements and model simulations from 1850 to 2100, J. Geophys. Res.-Atmos., 118, 7948-7961, https://doi.org/10.1002/jgrd.50612, 2013.

Bezeau, P., Sharp, M., Burgess, D., and Gascon, G.: Firn profile changes in response to extreme 21 st-century melting at Devon Ice Cap, Nunavut, Canada, J. Glaciol., 59, 981-991, https://doi.org/10.3189/2013JoG12J208, 2013.

Bisiaux, M. M., Edwards, R., McConnell, J. R., Curran, M. A. J., Van Ommen, T. D., Smith, A. M., Neumann, T. A., Pasteris, D. R., Penner, J. E., and Taylor, K.: Changes in black carbon deposition to Antarctica from two high-resolution ice core records, 1850-2000 AD, Atmos. Chem. Phys., 12, 4107-4115, https://doi.org/10.5194/acp-12-4107-2012, 2012.

Bond, T. C., Bhardwaj, E., Dong, R., Jogani, R., Jung, S. K., Roden, C., Streets, D. G., and Trautmann, N. M.: Historical emissions of black and organic carbon aerosol from energy-related combustion, 1850-2000, Global Biogeochem. Cy., 21, Gb2018, https://doi.org/10.1029/2006gb002840, 2007.

Bond, T. C., Doherty, S. J., Fahey, D. W., Forster, P. M., Berntsen, T., DeAngelo, B. J., Flanner, M. G., Ghan, S., Kärcher, B., Koch, D., Kinne, S., Kondo, Y., Quinn, P. K., Sarofim, M. C., Schultz, 
M. G., Schulz, M., Venkataraman, C., Zhang, H., Zhang, S., Bellouin, N., Guttikunda, S. K., Hopke, P. K., Jacobson, M. Z., Kaiser, J. W., Klimont, Z., Lohmann, U., Schwarz, J. P., Shindell, D., Storelvmo, T., Warren, S. G., and Zender, C. S.: Bounding the role of black carbon in the climate system: A scientific assessment, J. Geophys. Res.-Atmos., 118, 5380-5552, https://doi.org/10.1002/jgrd.50171, 2013.

Boon, S., Burgess, D. O., Koerner, R. M., and Sharp, M. J.: Fortyseven years of research on the Devon Island ice cap, Arctic Canada, Arctic, 63, 13-29, https://doi.org/10.14430/arctic643, 2010.

Browse, J., Carslaw, K. S., Arnold, S. R., Pringle, K., and Boucher, O.: The scavenging processes controlling the seasonal cycle in Arctic sulphate and black carbon aerosol, Atmos. Chem. Phys., 12, 6775-6798, https://doi.org/10.5194/acp12-6775-2012, 2012.

Buchardt, S. L., Clausen, H. B., Vinther, B. M., and Dahl-Jensen, D.: Investigating the past and recent $\delta^{18} \mathrm{O}$-accumulation relationship seen in Greenland ice cores, Clim. Past, 8, 2053-2059, https://doi.org/10.5194/cp-8-2053-2012, 2012.

Burn-Nunes, L. J., Vallelonga, P., Loss, R. D., Burton, G. R., Moy, A., Curran, M., Hong, S., Smith, A. M., Edwards, R., Morgan, V. I., and Rosman, K. J. R.: Seasonal variability in the input of lead, barium and indium to Law Dome, Antarctica, Geochim. Cosmochim. Acta., 75, 1-20, https://doi.org/10.1016/j.gca.2010.09.037, 2011.

Cheng, M. D.: Geolocating Russian sources for Arctic black carbon, Atmos. Environ., 92, 398-410, https://doi.org/10.1016/j.atmosenv.2014.04.031, 2014.

Colgan, W. and Sharp, M.: Combined oceanic and atmospheric influences on net accumulation on Devon Ice Cap, Nunavut, Canada. J. Glaciol., 54, 28-40, https://doi.org/10.3189/002214308784409044, 2008.

Dansgaard, W. and Johnsen, S. J.: A flow model and a time scale for the ice core from Camp Century, Greenland, J. Glaciol., 8, 215-223, https://doi.org/10.1017/S0022143000031208, 1969.

de la Peña, S., Howat, I. M., Nienow, P. W., van den Broeke, M. R., Mosley-Thompson, E., Price, S. F., Mair, D., Noël, B., and Sole, A. J.: Changes in the firn structure of the western Greenland Ice Sheet caused by recent warming, The Cryosphere, 9, 1203-1211, https://doi.org/10.5194/tc-9-1203-2015, 2015.

Doherty, S. J., Warren, S. G., Grenfell, T. C., Clarke, A. D., and Brandt, R. E.: Light-absorbing impurities in Arctic snow, Atmos. Chem. Phys., 10, 11647-11680, https://doi.org/10.5194/acp-1011647-2010, 2010.

Doherty, S. J., Grenfell, T. C., Forsström, S., Hegg, D. L., Brandt, R. E., and Warren, S. G.: Observed vertical redistribution of black carbon and other insoluble light-absorbing particles in melting snow, J. Geophys. Res.-Atmos., 118, 5553-5569, https://doi.org/10.1002/jgrd.50235, 2013.

Draxler, R. R. and Hess, G. D.: Description of the HYSPLIT 4 modeling system. NOAA Technical Memorandum ARL-224. Air Resources Laboratory, Silver Spring, Maryland, USA, 27 pp., 2014.

Ellis, A., Edwards, R., Saunders, M., Chakrabarty, R. K., Subramanian, R., van Riessen, A., Smith, A. M., Lambrinidis, D., Nunes, L. J., Vallelonga, P., Goodwin, I. D., Moy, A. D., Curran, M. A. J., and van Ommen, T. D.: Characterizing black carbon in rain and ice cores using coupled tangential flow filtration and transmis- sion electron microscopy, Atmos. Meas. Tech., 8, 3959-3969, https://doi.org/10.5194/amt-8-3959-2015, 2015.

Ellis, A., Edwards, R., Saunders, M., Chakrabarty, R. K., Subramanian, R., Timms, N. E., van Riessen, A., Smith, A. M., Lambrinidis, D., Nunes, L. J., and Vallelonga, P.: Individual particle morphology, coatings, and impurities of black carbon aerosols in Antarctic ice and tropical rainfall, Geophys. Res. Lett., 43,11875-11883, https://doi.org/10.1002/2016GL071042, 2016.

Fisher, D. A. and Koerner, R. M.: The effects of wind on $\delta^{18} \mathrm{O}$ and accumulation give an inferred record of seasonal amplitude from the Agassiz Ice Cap, Ellesmere Island, Canada, Ann. Glaciol., 10, 34-37, https://doi.org/10.1017/S0260305500004122, 1988.

Fisher, D. A., Koerner, R. M., Paterson, W. S. B., Dansgaard, W., Gundestrup, N., and Reeh, N.: Effect of wind scouring on climatic records from ice-core oxygen-isotope profiles, Nature, 301, 205-209, https://doi.org/10.1038/301205a0, 1983.

Fisher, D. A., Reeh, N., and Clausen, H. B.: Stratigraphic noise in time series derived from ice cores, Ann. Glaciol., 7, 76-83, https://doi.org/10.1017/S0260305500005942, 1985.

Fisher, D. A., Zheng, J., Burgess, D., Zdanowicz, C., Kinnard, C., Sharp, M., and Bourgeois, J.: Recent melt rates of Canadian Arctic ice caps are the highest in four millennia, Global Planet. Change, 84-85, 3-7, https://doi.org/10.1016/j.gloplacha.2011.06.005, 2012.

Garrett, T. J., Brattström, S., Sharma, S., Worthy, D. E. J., and Novelli, P.: The role of scavenging in the seasonal transport of black carbon and sulfate to the Arctic, Geophys. Res. Lett., 38, L16805, https://doi.org/10.1029/2011GL048221, 2011.

Gascon, G., Sharp, M., Burgess, D., Bezeau, P., and Bush, A. B. G.: Changes in accumulation-area firn stratigraphy and meltwater flow during a period of climate warming: Devon Ice Cap, Nunavut, Canada, J. Geophys. Res., 118, 2380-2391, https://doi.org/10.1002/2013JF002838, 2013.

Gfeller, G., Fischer, H., Bigler, M., Schüpbach, S., Leuenberger, D., and Mini, O.: Representativeness and seasonality of major ion records derived from NEEM firn cores, The Cryosphere, 8 , 1855-1870, https://doi.org/10.5194/tc-8-1855-2014, 2014.

Girardin, M. and Sauchyn, D.: Three centuries of annual area burned variability in northwestern North America inferred from tree rings, Holocene, 18, 205-214, https://doi.org/10.1177/0959683607086759, 2008.

Giradin, M. P.: Interannual to decadal changes in area burned in Canada from 1781 to 1982 and the relationship to Northern Hemisphere land temperatures, Global Ecol. Biogeogr., 16, 557566, https://doi.org/10.1111/j.1466-8238.2007.00321.x, 2007.

Girardin, M. P., Bergeron, Y., Tardif, J. C., Gauthier, S., Flannigan, M. D., and Mudelsee, M.: 229-year dendroclimaticinferred record of forest fire activity for the Boreal Shield of Canada, Int. J. Wildland Fire, 15, 375-388, https://doi.org/10.1071/WF05065, 2006.

Gong, S. L., Zhao,T. L., Sharma, S., Toom-Sauntry, D., Lavoué, D., Zhang, X. B., Leaitch, W. R., and Barrie, L. A.: Identification of trends and interannual variability of sulfate and black carbon in the Canadian High Arctic: 1981-2007, J. Geophys. Res., 115, D07305, https://doi.org/10.1029/2009JD012943, 2010.

Goto-Azuma, K. and Koerner, R. M.: Ice core studies of anthropogenic sulfate and nitrate trends in the Arctic. J. Geophys. Res., 206, 4959-4969, https://doi.org/10.1029/2000JD900635, 2001. 
Goto-Azuma, K., Koerner, R. M., and Fisher, D. A.: An ice-core record over the last two centuries from Penny Ice Cap, Baffin Island, Canada, Ann. Glaciol., 35, 29-25, 2002.

Grumet, N. S., Wake, C. P., Zielinski, G. A., Fisher, D. A., Koerner, R. M., and Jacobs, J. D.: Preservation of glaciochemical timeseries in snow and ice from the Penny Ice Cap, Baffin Island, Geophys. Res. Lett., 25, 357-360, 1998.

Hall, J. V. and Loboda, T. V.: Quantifying the potential for lowlevel transport of black carbon emissions from cropland burning in Russia to the snow-covered Arctic, Front. Earth Sci., 5, 109, https://doi.org/10.3389/feart.2017.00109, 2017.

Hirdman, D., Burkhart, J. F., Sodemann, H., Eckhardt, S., Jefferson, A., Quinn, P. K., Sharma, S., Ström, J., and Stohl, A.: Long-term trends of black carbon and sulphate aerosol in the Arctic: changes in atmospheric transport and source region emissions, Atmos. Chem. Phys., 10, 9351-9368, https://doi.org/10.5194/acp-109351-2010, 2010.

Huang, L., Gong, S. L., Sharma, S., Lavoué, D., and Jia, C. Q.: A trajectory analysis of atmospheric transport of black carbon aerosols to Canadian high Arctic in winter and spring (1990-2005), Atmos. Chem. Phys., 10, 5065-5073, https://doi.org/10.5194/acp-10-5065-2010, 2010.

Jiao, C. and Flanner, M. G.: Changing black carbon transport to the Arctic from present day to the end of $21 \mathrm{st}$ century, J. Geophys. Res.-Atmos., 121, 4734-4750, https://doi.org/10.1002/2015JD023964, 2016.

Jiao, C., Flanner, M. G., Balkanski, Y., Bauer, S. E., Bellouin, N., Berntsen, T. K., Bian, H., Carslaw, K. S., Chin, M., De Luca, N., Diehl, T., Ghan, S. J., Iversen, T., Kirkevåg, A., Koch, D., Liu, X., Mann, G. W., Penner, J. E., Pitari, G., Schulz, M., Seland, Ø., Skeie, R. B., Steenrod, S. D., Stier, P., Takemura, T., Tsigaridis, K., van Noije, T., Yun, Y., and Zhang, K.: An AeroCom assessment of black carbon in Arctic snow and sea ice, Atmos. Chem. Phys., 14, 2399-2417, https://doi.org/10.5194/acp14-2399-2014, 2014.

Kassomenos, P., Vardoulakis, S., Borge, R., Lumbreras, J., Papaloukas, C., and Karakitsios, S.: Comparison of statistical clustering techniques for the classification of modelled atmospheric trajectories, Theor. Appl. Climatol., 102, 1-12, https://doi.org/10.1007/s00704-009-0233-7, 2010.

Kekonen, T., Moore, J., Paavo Perämäki, P., Mulvaney, R., Isaksson, E., Pohjola, V., and van de Wal, R. S. W.: The 800 year long ion record from the Lomonosovfonna (Svalbard) ice core, J. Geophys. Res., 110, D07304, https://doi.org/10.1029/2004JD005223, 2005.

Kinnard, C., Zdanowicz, C. M., Fisher, D. A., and Wake, C. P.: Calibration of an ice-core glaciochemical (sea-salt) record with seaice variability in the Canadian Arctic, Ann. Glaciol., 44, 383390, https://doi.org/10.3189/172756406781811349, 2006.

Kistler, R., Kalnay, E., Collins, W., Saha, S., White, G., Woollen, J., Chelliah, M., Ebisuzaki, W., Kanamitsu, M., Kousky, V., Van Den Dool, H., Jenne, R., and Fiorino, M.: The NCEP-NCAR 50-year reanalysis: Monthly means CD-ROM and documentation, B. Am. Meteorol. Soc., 82, 247-267, https://doi.org/10.1175/15200477(2001)082<0247:TNNYRM>2.3.CO;2, 2001.

Koch, K., Bauer, S. E., Del Genio, A., Faluvegi, G., McConnell, J. R., Menon, S., Miller, R. L., Rind, D., Ruedy, R., Schmidt, G. A., and Shindell, D.: Coupled aerosol-chemistry-climate twentieth-century transient model investigation: Trends in shortlived species and climate responses, J. Climate, 24, 2693-2714, https://doi.org/10.1175/2011JCLI3582.1, 2011.

Krachler, M., Zheng, J., Koerner, R., Zdanowicz, C., Fisher, D., and Shotyk, W.: Increasing atmospheric antimony contamination in the northern hemisphere: snow and ice evidence from Devon Island, Arctic Canada, J. Environ. Monitor., 7, 1169-1176, 2005.

Lamarque, J.-F., Bond, T. C., Eyring, V., Granier, C., Heil, A., Klimont, Z., Lee, D., Liousse, C., Mieville, A., Owen, B., Schultz, M. G., Shindell, D., Smith, S. J., Stehfest, E., Van Aardenne, J., Cooper, O. R., Kainuma, M., Mahowald, N., McConnell, J. R., Naik, V., Riahi, K., and van Vuuren, D. P.: Historical (1850-2000) gridded anthropogenic and biomass burning emissions of reactive gases and aerosols: methodology and application, Atmos. Chem. Phys., 10, 7017-7039, https://doi.org/10.5194/acp-10-7017-2010, 2010.

Lee, Y. H., Lamarque, J.-F., Flanner, M. G., Jiao, C., Shindell, D. T., Berntsen, T., Bisiaux, M. M., Cao, J., Collins, W. J., Curran, M., Edwards, R., Faluvegi, G., Ghan, S., Horowitz, L. W., McConnell, J. R., Ming, J., Myhre, G., Nagashima, T., Naik, V., Rumbold, S. T., Skeie, R. B., Sudo, K., Takemura, T., Thevenon, F., Xu, B., and Yoon, J.-H.: Evaluation of preindustrial to present-day black carbon and its albedo forcing from Atmospheric Chemistry and Climate Model Intercomparison Project (ACCMIP), Atmos. Chem. Phys., 13, 2607-2634, https://doi.org/10.5194/acp-13-2607-2013, 2013.

Legrand, M., McConnell, J., Fischer, H., Wolff, E. W., Preunkert, S., Arienzo, M., Chellman, N., Leuenberger, D., Maselli, O., Place, P., Sigl, M., Schüpbach, S., and Flannigan, M.: Boreal fire records in Northern Hemisphere ice cores: a review, Clim. Past, 12, 2033-2059, https://doi.org/10.5194/cp-12-2033-2016, 2016.

Liu, D., Allan, J., Whitehead, J., Young, D., Flynn, M., Coe, H., McFiggans, G., Fleming, Z. L., and Bandy, B.: Ambient black carbon particle hygroscopic properties controlled by mixing state and composition, Atmos. Chem. Phys., 13, 2015-2029, https://doi.org/10.5194/acp-13-2015-2013, 2013.

Liu, J., Fan, S., Horowitz, L. W., and Levy, H.: Evaluation of factors controlling long-range transport of black carbon to the Arctic, J. Geophys. Res., 116, D04307, https://doi.org/10.1029/2010JD015145, 2011.

Machguth, H., MacFerrin, M., van As, D., Box, J. E., Charalampidis, C., Colgan, W., Fausto, R. S., Meijer, H. A. J., MosleyThompson, E., and van deWal, R. S. W.: Greenland meltwater storage in firn limited by near-surface ice formation, Nat. Clim. Change, 6, 390-393, https://doi.org/10.1038/NCLIMATE2899, 2016.

Massling, A., Nielsen, I. E., Kristensen, D., Christensen, J. H., Sørensen, L. L., Jensen, B., Nguyen, Q. T., Nøjgaard, J. K., Glasius, M., and Skov, H.: Atmospheric black carbon and sulfate concentrations in Northeast Greenland, Atmos. Chem. Phys., 15, 9681-9692, https://doi.org/10.5194/acp-15-9681-2015, 2015.

McConnell, J. R.: New directions: Historical black carbon and other ice core aerosol records in the Arctic for GCM evaluation, Atmos. Environ., 44, 2665-2666, https://doi.org/10.1016/j.atmosenv.2010.04.004, 2010.

McConnell, J. R. and Edwards, R.: Coal burning leaves toxic heavy metal legacy in the Arctic, P. Natl. Acad. Sci. USA, 105, 1214012144, https://doi.org/10.1073/pnas.0803564105, 2008. 
McConnell, J. R., Lamorey, G. W., Lambert, S. W., and Taylor, K. C.:Continuous ice-core chemical analyses using inductively coupled plasma mass spectrometry, Environ. Sci. Technol., 36, 7-11, https://doi.org/10.1021/es011088z, 2002.

McConnell, J. R., Edwards, R., Kok, G. L., Flanner, M. G., Zender, C. S., Saltzman, E. S., Banta, J. R., Pasteris, D. R., Carter, M. M., and Kahl, J. D.: 20th-century industrial black carbon emissions altered Arctic climate forcing, Science, 317, 1381-1384, https://doi.org/10.1126/science.1144856, 2007.

Miller, J. E., Kahl, J. D. W., Heller, F., and Harris, J. M.: A threedimensional residence-time analysis of potential summertime atmospheric transport to Summit, Greenland, Ann. Glaciol., 35, 403-408, https://doi.org/10.3189/172756402781816663, 2002.

Mouillot, F. and Field, C. B.: Fire history and the global carbon budget: a $1 \times 1^{\circ}$ fire history reconstruction for the 20th century, Glob. Change Biol., 11, 398-420, https://doi.org/10.1111/j.13652486.2005.00920.x, 2005.

Novakov, T., Ramanathan, V., Hansen, J. E., Kirchstetter, T. W., Sato, M., Sinton, J. E., and Sathaye, J. A.: Large historical changes of fossil-fuel black carbon aerosols, Geophys. Res. Lett., 30, 1324, https://doi.org/10.1029/2002GL016345, 2003.

Paris, J.-D., Stohl, A., Nédélec, P., Arshinov, M. Yu., Panchenko, M. V., Shmargunov, V. P., Law, K. S., Belan, B. D., and Ciais, P.: Wildfire smoke in the Siberian Arctic in summer: source characterization and plume evolution from airborne measurements, Atmos. Chem. Phys., 9, 9315-9327, https://doi.org/10.5194/acp9-9315-2009, 2009.

Petzold, A., Ogren, J. A., Fiebig, M., Laj, P., Li, S.-M., Baltensperger, U., Holzer-Popp, T., Kinne, S., Pappalardo, G., Sugimoto, N., Wehrli, C., Wiedensohler, A., and Zhang, X.-Y.: Recommendations for reporting "black carbon" measurements, Atmos. Chem. Phys., 13, 8365-8379, https://doi.org/10.5194/acp13-8365-2013, 2013.

Pilson, M. E. O.: An Introduction to the Chemistry of the Sea, 2nd edition, Cambridge: Cambridge University Press, 533 pp., 2012.

Pinglot, J. F., Vaikmäe, R. A., Kamiyama, K, Igarashi, M., Fritzsche, D., Wilhelms, F., Koerner, R., Henderson, L., Isaksson, E., Winther, J.-G., van de Wal, R. S. W., Fournier, M., Bouisset, P., and Meijer, H. A. J.: Ice cores from Arctic subpolar glaciers: chronology and post-depositional processes deduced from radioactivity measurements, J. Glaciol., 49, 149-158, https://doi.org/10.3189/172756503781830944, 2013.

Quennehen, B., Schwarzenboeck, A., Matsuki, A., Burkhart, J. F., Stohl, A., Ancellet, G., and Law, K. S.: Anthropogenic and forest fire pollution aerosol transported to the Arctic: observations from the POLARCAT-France spring campaign, Atmos. Chem. Phys., 12, 6437-6454, https://doi.org/10.5194/acp12-6437-2012, 2012.

Quinn, P. K., Bates, T. S., Baum, E., Doubleday, N., Fiore, A. M., Flanner, M., Fridlind, A., Garrett, T. J., Koch, D., Menon, S., Shindell, D., Stohl, A., and Warren, S. G.: Shortlived pollutants in the Arctic: their climate impact and possible mitigation strategies, Atmos. Chem. Phys., 8, 1723-1735, https://doi.org/10.5194/acp-8-1723-2008, 2008.

Ruppel, M. M., Isaksson, E., Ström, J., Beaudon, E., Svensson, J., Pedersen, C. A., and Korhola, A.: Increase in elemental carbon values between 1970 and 2004 observed in a 300year ice core from Holtedahlfonna (Svalbard), Atmos. Chem.
Phys., 14, 11447-11460, https://doi.org/10.5194/acp-14-114472014, 2014.

Schwarz, J. P., Spackman, J. R., Gao, R. S., Perring, A. E., Cross, E., Onasch, T. B., Ahern, A., Wrobel, W., Davidovits, P., Olfert, J., Dubey, M. K., Mazzoleni, C., and Fahey, D. W.: The detection efficiency of the single particle soot photometer, Aerosol Sci. Technol., 44, 612-628, https://doi.org/10.1080/02786826.2010.481298, 2010.

Schwarz, J. P., Doherty, S. J., Li, F., Ruggiero, S. T., Tanner, C. E., Perring, A. E., Gao, R. S., and Fahey, D. W.: Assessing Single Particle Soot Photometer and Integrating Sphere/Integrating Sandwich Spectrophotometer measurement techniques for quantifying black carbon concentration in snow, Atmos. Meas. Tech., 5, 2581-2592, https://doi.org/10.5194/amt-5-2581-2012, 2012.

Schwarz, J. P., Gao, R. S., Perring, A. E., Spackman, J. R., and Fahey, D. W.: Black carbon aerosol size in snow, Sci. Rep., 3, 1356, https://doi.org/10.1038/srep01356, 2013.

Sharma, S., Andrews, E., Barrie, L. A., Ogren, J. A., and Lavoué, D.: Variations and sources of the equivalent black carbon in the High Arctic revealed by long-term observations at Alert and Barrow: 1989-2003, J. Geophys. Res., 111, D14208, https://doi.org/10.1029/2005JD006581, 2006.

Shen, Z., Ming, Y., Horowitz, L. W., Ramaswamy, V., and Lin, M.: On the seasonality of Arctic black carbon, J. Climate, 30, 4429_ 4441, https://doi.org/10.1175/JCLI-D-16-0580.1, 2017.

Shindell, D. T., Chin, M., Dentener, F., Doherty, R. M., Faluvegi, G., Fiore, A. M., Hess, P., Koch, D. M., MacKenzie, I. A., Sanderson, M. G., Schultz, M. G., Schulz, M., Stevenson, D. S., Teich, H., Textor, C., Wild, O., Bergmann, D. J., Bey, I., Bian, H., Cuvelier, C., Duncan, B. N., Folberth, G., Horowitz, L. W., Jonson, J., Kaminski, J. W., Marmer, E., Park, R., Pringle, K. J., Schroeder, S., Szopa, S., Takemura, T., Zeng, G., Keating, T. J., and Zuber, A.: A multi-model assessment of pollution transport to the Arctic, Atmos. Chem. Phys., 8, 5353-5372, https://doi.org/10.5194/acp-8-5353-2008, 2008.

Shotyk, W., Zheng, J., Krachler, M., Zdanowicz, C., Koerner, R., and Fisher, D.: Predominance of industrial $\mathrm{Pb}$ in recent snow (1994-2004) and ice (1842-1996) from Devon Island, Arctic Canada, Geophys. Res. Lett., 32, L21814, https://doi.org/10.1029/2005GL023860, 2005.

Simoneit, B. R. T.: Biomass burning: A review of organic tracers for smoke from incomplete combustion, Appl. Geochem., 17, 129162, https://doi.org/10.1016/S0883-2927(01)00061-0, 2002.

Skeie, R. B., Berntsen, T., Myhre, G., Pedersen, C. A., Ström, J., Gerland, S., and Ogren, J. A.: Black carbon in the atmosphere and snow, from pre-industrial times until present, Atmos. Chem. Phys., 11, 6809-6836, https://doi.org/10.5194/acp11-6809-2011, 2011.

Sigl, M., Winstrup, M., McConnell, J. R., Welten, K. C., Plunkett, G., Ludlow, F., Büntgen, U., Caffee, M., Chellman, N., DahlJensen, D., Kipfstuhl, S., Kostick, C., Maselli, O. J., Mekhaldi, F., Mulvaney, R., Muscheler, R., Pasteris, D. R., Pilcher, J. R., Salzer, M., Schüpbach, S., Steffensen, J. P., Vinther, B. M., and Woodruff, T. E.: Timing and climate forcing of volcanic eruptions for the past 2,500 years, Nature, 523, 543-549, https://doi.org/10.1038/nature14565, 2015.

Stein, A. F., Draxler, R. R., Rolph, G. D., Stunder, B. J. B., Cohen, M. D., and Ngan, F.: NOAA's HYSPLIT atmospheric transport and dispersion modeling system, B. Am. Meteo- 
rol. Soc., 96, 2050-2077, https://doi.org/10.1175/BAMS-D-14$00110.1,2015$.

Stohl, A., Andrews, E., Burkhart, J. F., Forster, C., Herber, A., Hoch, S. W., Kowal, D., Lunder, C., Mefford, T., Ogren, J. A., Sharma, S., Spichtinger, N., Stebel, K., Stone, R., Ström, J.,Tørseth, K., Wehrli, C., and Yttri, K. E.: Pan-Arctic enhancements of light absorbing aerosol concentrations due to North American boreal forest fires during summer 2004, J. Geophys. Res., 111, D22214, https://doi.org/10.1029/2006JD007216, 2006.

Su, L., Yuan, Z., Fung, J. C. H., and Lau, A. K. H.: A comparison of HYSPLIT backward trajectories generated from two GDAS datasets, Sci. Total Environ., 506-507, 527-537, https://doi.org/10.1016/j.scitotenv.2014.11.072, 2015.

Tuohy, A., Bertler, N., Neff, P., Edwards, R., Emanuelsson, D., Beers, T., and Mayewski, P.: Transport and deposition of heavy metals in the Ross Sea Region, Antarctica, J. Geophys. Res.-Atmos., 120, 10996-11011, https://doi.org/10.1002/2015JD023293, 2015.

Vallelonga, P., Maffezzoli, N., Moy, A. D., Curran, M. A. J., Vance, T. R., Edwards, R., Hughes, G., Barker, E., Spreen, G., SaizLopez, A., Corella, J. P., Cuevas, C. A., and Spolaor, A.: Sea-icerelated halogen enrichment at Law Dome, coastal East Antarctica, Clim. Past, 13, 171-184, https://doi.org/10.5194/cp-13-1712017, 2017.

van de Wal, R. S., Mulvaney, R., Isaksson, E., Moore, J. C., Pinglot, J.-F., Pohjola, V. A., and Thomassen, M. P. A.: Reconstruction of the historical temperature trend from measurements in a medium-length borehole on the Lomonosovfonna plateau, Svalbard, Ann. Glaciol., 35, 371-378, https://doi.org/10.3189/172756402781816979, 2002.

Vega, C. P., Pohjola, V. A., Beaudon, E., Claremar, B., van Pelt, W. J. J., Pettersson, R., Isaksson, E., Martma, T., Schwikowski, M., and Bøggild, C. E.: A synthetic ice core approach to estimate ion relocation in an ice field site experiencing periodical melt: a case study on Lomonosovfonna, Svalbard, The Cryosphere, 10, 961-976, https://doi.org/10.5194/tc-10-961-2016, 2016.

Viatte, C., Strong, K., Hannigan, J., Nussbaumer, E., Emmons, L. K., Conway, S., Paton-Walsh, C., Hartley, J., Benmergui, J., and Lin, J.: Identifying fire plumes in the Arctic with tropospheric FTIR measurements and transport models, Atmos. Chem. Phys., 15, 2227-2246, https://doi.org/10.5194/acp-152227-2015, 2015.

Warneke, C., Bahreini, R., Brioude, J., Brock, C. A., de Gouw, A. Fahey, D. W., Froyd, K. D., Holloway, J. S., Middlebrook, A., Miller, L., Montzka, S., Murphy, D. M., Peischl, J., Ryerson, T. B., Schwarz, J. P., Spackman, J. R., and Veres, P.: Biomass burning in Siberia and Kazakhstan as an important source for haze over the Alaskan Arctic in April 2008, J. Geophys. Res., 36, L02813, https://doi.org/10.1029/2008GL036194, 2009.
Wendl, I. A., Menking, J. A., Färber, R., Gysel, M., Kaspari, S. D., Laborde, M. J. G., and Schwikowski, M.: Optimized method for black carbon analysis in ice and snow using the Single Particle Soot Photometer, Atmos. Meas. Tech., 7, 2667-2681, https://doi.org/10.5194/amt-7-2667-2014, 2014.

Wentworth, G. R., Murphy, J. G., Croft, B., Martin, R. V., Pierce, J. R., Côté, J.-S., Courchesne, I., Tremblay, J.-É., Gagnon, J., Thomas, J. L., Sharma, S., Toom-Sauntry, D., Chivulescu, A., Levasseur, M., and Abbatt, J. P. D.: Ammonia in the summertime Arctic marine boundary layer: sources, sinks, and implications, Atmos. Chem. Phys., 16, 1937-1953, https://doi.org/10.5194/acp-16-1937-2016, 2016.

Zdanowicz, C., Zielinski, G., and Wake, C.: Characteristics of modern atmospheric dust deposition in snow on Penny Ice Cap, Baffin Island, Arctic Canada, Tellus, 50B, 506-520, https://doi.org/10.3402/tellusb.v50i5.16234, 1998.

Zdanowicz, C., Smetny-Sowa, A., Fisher, D., Schaffer, N., Copland, L., and Eley, J.: Summer melt rates on Penny ice cap, Baffin Island: Past and recent trends, and implications for regional climate, J. Geophys. Res.-Earth Surf., 117, F02006, https://doi.org/10.1029/2011JF002248, 2012.

Zennaro, P., Kehrwald, N., McConnell, J. R., Schüpbach, S., Maselli, O. J., Marlon, J., Vallelonga, P., Leuenberger, D., Zangrando, R., Spolaor, A., Borrotti, M., Barbaro, E., Gambaro, A., and Barbante, C.: Fire in ice: two millennia of boreal forest fire history from the Greenland NEEM ice core, Clim. Past, 10, 1905-1924, https://doi.org/10.5194/cp-10-1905-2014, 2014.

Zheng, J., Kudo, A., Fisher, D., Blake, E., and Gerasimoff, M.: Solid electrical conductivity (ECM) from four Agassiz ice cores, Ellesmere Island NWT, Canada: highresolution signal and noise over the last millennium and low resolution over the Holocene, Holocene, 8, 413-421, https://doi.org/10.1191/095968398676187747, 1998.

Zheng, J., Shotyk, W., Krachler, M., and Fisher, D. A.: A 15,800-year record of atmospheric lead deposition on the Devon Island Ice Cap, Nunavut, Canada: Natural and anthropogenic enrichments, isotopic composition, and predominant sources, Global Biogeochem. Cy., 21, GB2027, https://doi.org/10.1029/2006GB002897, 2007. 